\title{
Article
}

\section{Rapid Hormetic Responses of Photosystem II Photochemistry of Clary Sage to Cadmium Exposure}

\author{
Ioannis-Dimosthenis S. Adamakis ${ }^{1, *}$, Ilektra Sperdouli ${ }^{2} \mathbb{D}$, Anetta Hanć ${ }^{3}$, Anelia Dobrikova ${ }^{4}{ }^{\circ}$, \\ Emilia Apostolova ${ }^{4}$ and Michael Moustakas ${ }^{5, *(D)}$ \\ 1 Department of Botany, Faculty of Biology, National and Kapodistrian University of Athens, \\ 15784 Athens, Greece \\ 2 Institute of Plant Breeding and Genetic Resources, Hellenic Agricultural Organization-Demeter, Thermi, \\ 57001 Thessaloniki, Greece; ilektras@bio.auth.gr \\ 3 Department of Trace Analysis, Faculty of Chemistry, Adam Mickiewicz University, 61-614 Poznań, Poland; \\ anettak@amu.edu.pl \\ 4 Institute of Biophysics and Biomedical Engineering, Bulgarian Academy of Sciences, 1113 Sofia, Bulgaria; \\ aneli@bio21.bas.bg (A.D.); emya@bio21.bas.bg (E.A.) \\ 5 Department of Botany, Aristotle University of Thessaloniki, 54124 Thessaloniki, Greece \\ * Correspondence: iadamaki@biol.uoa.gr (I.-D.S.A.); moustak@bio.auth.gr (M.M.)
}

Citation: Adamakis, I.S.; Sperdouli, I.; Hanć, A.; Dobrikova, A.; Apostolova, E.; Moustakas, M. Rapid Hormetic Responses of Photosystem II Photochemistry of Clary Sage to Cadmium Exposure. Int. J. Mol. Sci. 2021, 22, 41. https://dx.doi.org/ 10.3390/ijms22010041

Received: 8 November 2020 Accepted: 17 December 2020 Published: 22 December 2020

Publisher's Note: MDPI stays neutral with regard to jurisdictional claims in published maps and institutional affiliations.

Copyright: () 2020 by the authors. Licensee MDPI, Basel, Switzerland. This article is an open access article distributed under the terms and conditions of the Creative Commons Attribution (CC BY) license (https: / / creativecommons.org/ licenses/by/4.0/).

\begin{abstract}
Five-day exposure of clary sage (Salvia sclarea L.) to $100 \mu \mathrm{M}$ cadmium (Cd) in hydroponics was sufficient to increase $\mathrm{Cd}$ concentrations significantly in roots and aboveground parts and affect negatively whole plant levels of calcium (Ca) and magnesium (Mg), since $\mathrm{Cd}$ competes for $\mathrm{Ca}$ channels, while reduced $\mathrm{Mg}$ concentrations are associated with increased $\mathrm{Cd}$ tolerance. Total zinc $(\mathrm{Zn})$, copper $(\mathrm{Cu})$, and iron $(\mathrm{Fe})$ uptake increased but their translocation to the aboveground parts decreased. Despite the substantial levels of $\mathrm{Cd}$ in leaves, without any observed defects on chloroplast ultrastructure, an enhanced photosystem II (PSII) efficiency was observed, with a higher fraction of absorbed light energy to be directed to photochemistry $\left(\Phi_{P S I I}\right)$. The concomitant increase in the photoprotective mechanism of non-photochemical quenching of photosynthesis (NPQ) resulted in an important decrease in the dissipated non-regulated energy $\left(\Phi_{N O}\right)$, modifying the homeostasis of reactive oxygen species (ROS), through a decreased singlet oxygen $\left({ }^{1} \mathrm{O}_{2}\right)$ formation. A basal ROS level was detected in control plant leaves for optimal growth, while a low increased level of ROS under 5 days $\mathrm{Cd}$ exposure seemed to be beneficial for triggering defense responses, and a high level of ROS out of the boundaries ( 8 days $\mathrm{Cd}$ exposure), was harmful to plants. Thus, when clary sage was exposed to $\mathrm{Cd}$ for a short period, tolerance mechanisms were triggered. However, exposure to a combination of $\mathrm{Cd}$ and high light or to Cd alone (8 days) resulted in an inhibition of PSII functionality, indicating $\mathrm{Cd}$ toxicity. Thus, the rapid activation of PSII functionality at short time exposure and the inhibition at longer duration suggests a hormetic response and describes these effects in terms of "adaptive response" and "toxicity", respectively.
\end{abstract}

Keywords: Salvia sclarea; chlorophyll fluorescence imaging; non-photochemical quenching; tolerance mechanism; photoprotective mechanism; oxidative stress; reactive oxygen species; toxicity; adaptive response; photochemical efficiency

\section{Introduction}

Cadmium (Cd) is occurring in soils at low concentrations but can arise to high concentrations as a result of numerous human activities, while being not biodegradable in the soil, it is considered as one of the most toxic elements, and also a non-essential element for plants [1-6]. Cadmium is taken up by roots, and its translocation from the roots to the shoots and leaves with subsequent accumulation in the chloroplasts, will eventually disturb photosynthesis [7]. However, many plant species have established numerous special effective mechanisms for Cd detoxification and tolerance [4-6]. 
Cadmium tolerance is related with declines of the internal Cd accumulation [8] but some plant species are able to sustain growth or even improve their growth and functioning under $\mathrm{Cd}$ exposure, despite a high $\mathrm{Cd}$ accumulation in roots and shoots [9-11]. Foliar Cd content above $0.01 \%$ dry biomass $\left(100 \mu \mathrm{g} \mathrm{g}^{-1}\right)$ is considered extraordinary and a limit value for $\mathrm{Cd}$ hyperaccumulation $[7,12]$.

Plants can cope with stress by a plethora of structural and functional mechanisms while low-level stress or short duration exposure stimulates plant performance [13-19]. This can be achieved through the involvement of a basal level of reactive oxygen species (ROS) [20-25], which are regulated by the non-photochemical quenching (NPQ) photoprotective mechanism of photosynthesis $[19,22,26,27]$. An elevated NPQ reduces the electron transport rate (ETR), avoiding ROS formation $[28,29]$. ROS generation can be a direct consequence to photosystem II (PSII) damage or can inhibit the repair of PSII reaction centers [29-32].

Dose-response studies are proposing hormesis as a central dose-response phenomenon for a variety of stressors [8,33-38]. Hormesis is a widespread phenomenon usually in nature, independent of the kind of stressor, the physiological process, or the organism it occurs [8,33-36]. It is described as the stimulatory effect of low doses or short exposure times, described by a biphasic dose-response with a low dose stimulation and a high dose inhibition [39-41] representing an "over-compensation" response to a disruption in homeostasis [42].

Salvia sclarea (clary sage) is a flowering herb that is native in the Mediterranean basin area, possessing pharmacological activities, and being traditional used as a treatment for eye health and hair tonic. It is used for pharmaceutical purposes, having antibacterial properties, while in aromatherapy, clary sage essential oil is used to alleviate stress acting as an anti-stressor, and when inhaled, it elicits feelings of relaxation and helps to reduce blood pressure [43]. S. sclarea is tolerant to heavy metals and has been characterized as an $\mathrm{Zn}$ and $\mathrm{Cd}$ accumulator, while its essential oils are not contaminated with heavy metals [44].

Since any substantial effect on plant growth after exposure to $\mathrm{Cd}$ can be detected only if photosynthesis is disturbed [45], a hormetic response to Cd is frequently coupled with changes in the mechanisms of photosynthesis or the photosynthetic apparatus [8]. The toxic effects of $\mathrm{Cd}$ provoke oxidative stress in plants and are related with the production of ROS $[4,36,46,47]$ that can be regulated by NPQ in such a way so that plants can cope with the stress $[19,22,26,27]$. Therefore, it was hypothesized that after exposure of clary sage to $\mathrm{Cd}$, the photosynthetic machinery could display a hormetic response to $\mathrm{Cd}$, if plant tolerance mechanisms were activated and photosystem II photochemistry could be regulated by the photoprotective mechanism of NPQ in a such way that PSII functionality is enhanced without any chloroplast ultrastructure perturbations.

\section{Results}

\subsection{Cadmium Accumulation and Elemental Concentrations}

Upon exposure of plants to $100 \mu \mathrm{M} \mathrm{Cd}$ in hydroponics, Cd concentrations of aboveground tissues (shoot-leaves) and roots increased $(p<0.05)$ by 31-fold (Figure 1a) and 2900-fold (Figure 1b) respectively, with Cd ions to be retained almost exclusively in the roots and reaching $23,941 \pm 715 \mu \mathrm{g} \mathrm{g}^{-1}$ vs. $53.3 \pm 1.6 \mu \mathrm{g} \mathrm{g}^{-1}$ in the aboveground tissues. Cadmium exposure enhanced total $\mathrm{Zn}, \mathrm{Cu}$, and Fe uptake by 2.1-fold (Figure 2a), 1.7-fold (Figure 2b), and 1.5-fold (Figure 2c) respectively, but decreased their translocation to the leaves by $45 \%, 16 \%$, and $60 \%$, respectively. Zinc, $\mathrm{Cu}$, and Fe content in roots after $\mathrm{Cd}$ exposure reached $542 \pm 16,112.2 \pm 3.5$, and $1696 \pm 51 \mu^{-1} \mathrm{~g} \mathrm{~g}^{-1}$ from $195.4 \pm 5.8,60.6 \pm 1.8$, and $945 \pm 28 \mathrm{\mu g} \mathrm{g}^{-1}$, respectively, while in aboveground tissues from $72.9 \pm 2.2,12.24 \pm 0.36$, and $224.8 \pm 6.7 \mu \mathrm{g} \mathrm{g}^{-1}$, decreased to $32.58 \pm 1.6,10.29 \pm 0.28$, and $88.4 \pm 2.6 \mu \mathrm{g} \mathrm{g}^{-1}$, respectively. Total Ca uptake was significantly reduced (58\%), with root $\mathrm{Ca}$ accumulation to remain almost unaffected, but $\mathrm{Ca}$ translocation to shoot-leaves to be significantly reduced (84\%) (Figure 2e). Thus, after Cd exposure, Ca content in roots was 10,122 $\pm 304 \mu \mathrm{g} \mathrm{g}^{-1}$ from 10,005 $\pm 300 \mathrm{\mu g} \mathrm{g}^{-1}$ before $\mathrm{Cd}$ treatment, but in the aboveground tissues, decreased to 
$3820 \pm 115 \mu \mathrm{g} \mathrm{g}^{-1}$ from that of 23,484 $\pm 704 \mu \mathrm{g} \mathrm{g}^{-1}$ before Cd treatment (Figure 2e). Total $\mathrm{Mn}$ (Figure $2 \mathrm{~d}$ ) and $\mathrm{Mg}$ (Figure $2 \mathrm{f}$ ) uptake decreased $(p<0.05)$ by $5 \%$ and $49 \%$, respectively, after $\mathrm{Cd}$ exposure, but while $\mathrm{Mg}$ accumulation decreased in both roots $(43 \%)$ and shootsleaves (53\%) (Figure 2f), Mn accumulation increased in roots (1.6-fold), but its translocation to the shoots decreased (65\%) after $\mathrm{Cd}$ exposure (Figure 2d). Manganese increased in roots

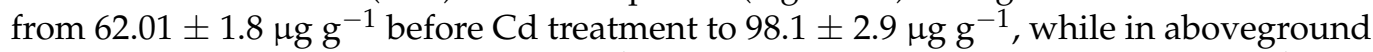
tissues decreased from $64.2 \pm 1.9 \mu \mathrm{g} \mathrm{g}^{-1}$ before Cd treatment to $22.88 \pm 0.69 \mu \mathrm{g} \mathrm{g}^{-1}$ after $\mathrm{Cd}$ exposure (Figure 2d). Magnesium, the next most negatively affected element after $\mathrm{Ca}$, decreased in roots from $4184 \pm 126 \mu \mathrm{g} \mathrm{g}^{-1}$ before Cd treatment to $2391 \pm 72 \mu \mathrm{g} \mathrm{g}^{-1}$ after $\mathrm{Cd}$ exposure, while in aboveground tissues from $5851 \pm 175 \mathrm{\mu g} \mathrm{g}^{-1}$ before $\mathrm{Cd}$ treatment to $2778 \pm 83 \mu \mathrm{g} \mathrm{g}^{-1}$ after $\mathrm{Cd}$ exposure (Figure 2f).
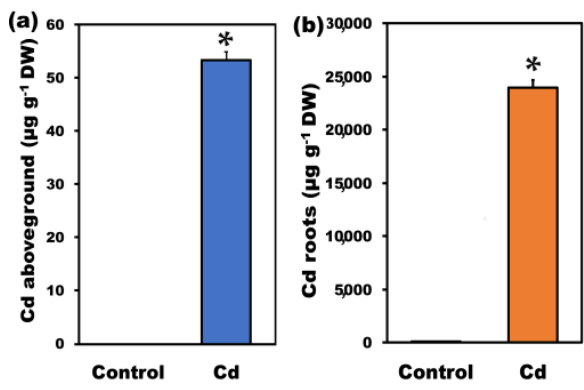

Figure 1. Changes of $\mathrm{Cd}$ accumulation in aboveground (shoots-leaves) tissues (a) and roots (b), in $\mu \mathrm{g} \mathrm{g}^{-1}$ dry weight, after 5 days $\mathrm{Cd}$ treatment of Salvia sclarea plants. Error bars are standard deviations $(n=5)$. Means between the two treatments that are statistically different $(p<0.05)$ are marked by an asterisk $\left({ }^{*}\right)$.
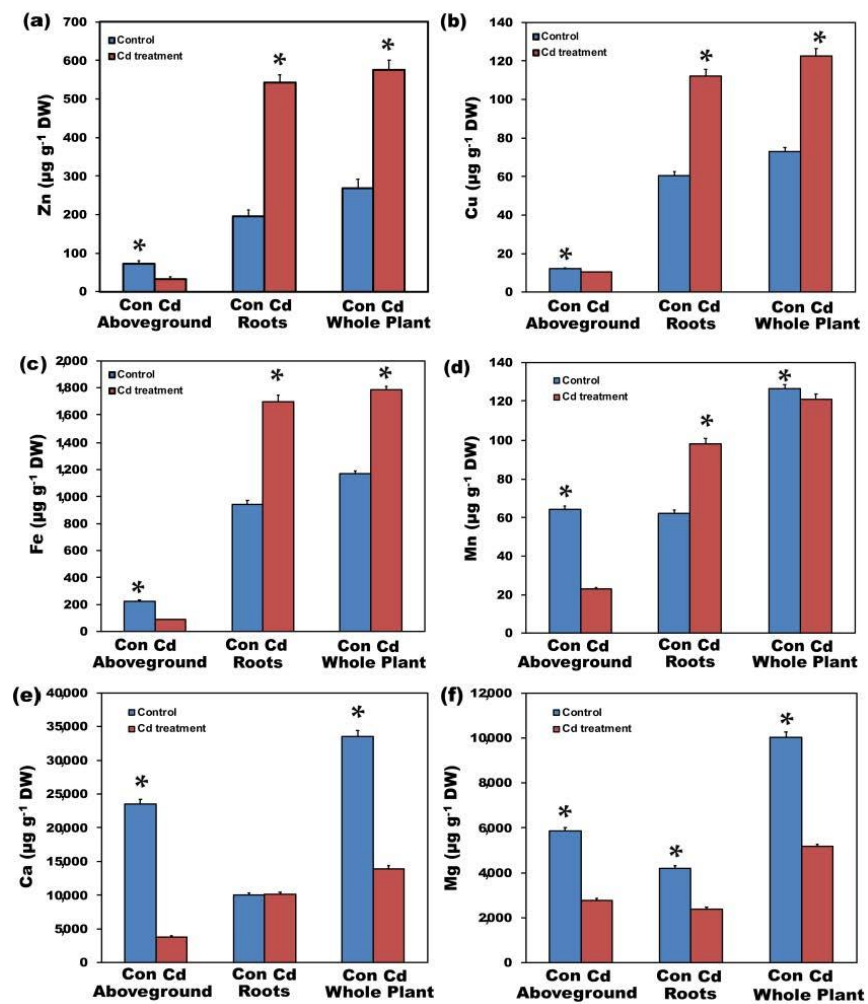

Figure 2. Zinc (a), $\mathrm{Cu}(\mathbf{b}), \mathrm{Fe}(\mathbf{c}), \mathrm{Mn}(\mathbf{d}), \mathrm{Ca}(\mathbf{e})$, and $\mathrm{Mg}$ (f) content, in $\mu \mathrm{g} \mathrm{g}^{-1}$ dry weight, of control (con) and 5 days Cd-treated Salvia sclarea aboveground (shoots-leaves) tissues, roots, and whole plants. Error bars are standard deviations $(n=5)$. Means between the two treatments that are statistically different $(p<0.05)$ are marked by an asterisk $\left(^{*}\right)$. 


\subsection{Chlorophyll $a$ and Chlorophyll $b$ Content after Cadmium Exposure}

Chlorophyll a (Chla) content decreased $(p<0.05)$ in S. sclarea leaves exposed to Cd for 2 and 5 days compared to their respective controls (Figure 3a). The same response pattern was observed in chlorophyll $b(\mathrm{Chl} b)$ content of $S$. sclarea leaves after 2- and 5-days exposure to $\mathrm{Cd}$ stress (Figure $3 \mathrm{~b}$ ). These significant chlorophyll content decreases can be explained by the significantly decreased $\mathrm{Mg}$ uptake (Figure 2f).
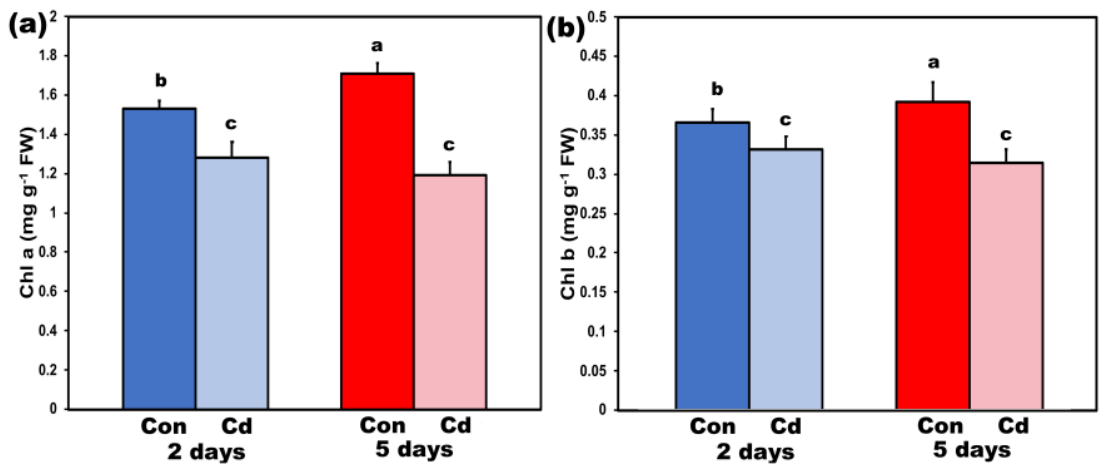

Figure 3. Chlorophyll $a$ content (a) and chlorophyll $b$ content (b), in $\mathrm{mg} \mathrm{g}^{-1}$ fresh weight, of control (con) and 2- and 5-days Cd-treated Salvia sclarea plants. Error bars are standard deviations $(n=6)$. Columns with different letters are statistically different $(p<0.05)$.

\subsection{The Efficiency of Photosystem II after Cadmium Exposure}

In order to understand how PSII functionality is affected by exposure of plants to Cd, we measured the maximum efficiency of PSII photochemistry (Fv/Fm) (Figure 4a) and the efficiency of the water-splitting complex on the donor side of PSII ( $\mathrm{Fv} / \mathrm{Fo}$ ) [29] (Figure 4b). Both parameters increased $(p<0.05)$ in $S$. sclarea plants exposed to $\mathrm{Cd}$ stress for 2 and 5 days compared to their respective controls, indicating an enhanced PSII functionality under Cd stress. However, this enhanced PSII functionality up to 5 days exposure had not any significant influence on plant biomass, but 8 days $\mathrm{Cd}$ exposure reduced whole plant biomass by $18 \%(p<0.05)$.
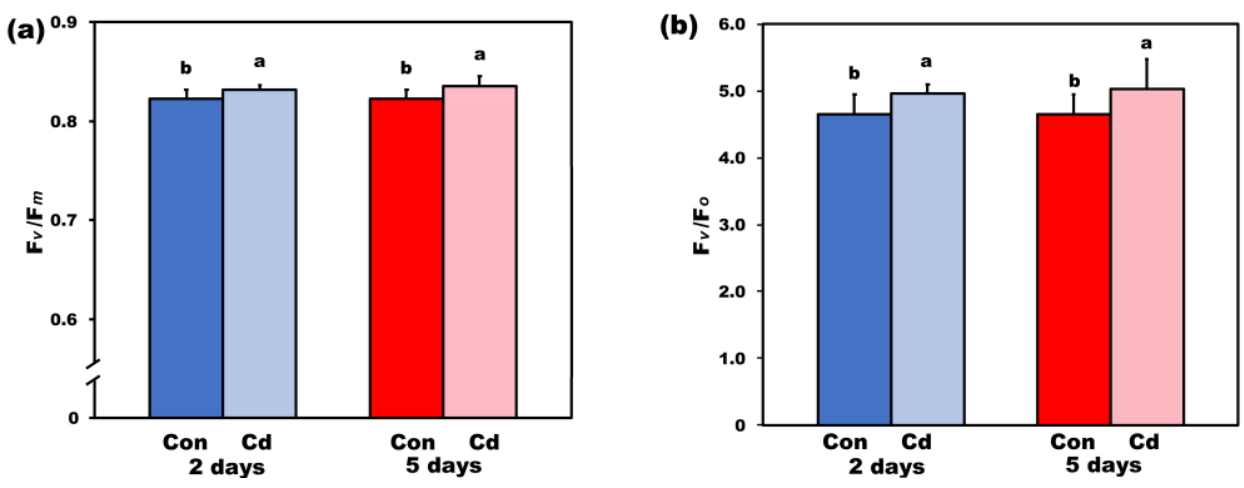

Figure 4. The maximum efficiency of photosystem II (PSII) photochemistry (Fv/Fm) (a), and the efficiency of the water-splitting complex on the donor side of PSII (Fv/Fo) (b), of control (con) and 2and 5-days Cd-treated Salvia sclarea plants. Error bars are standard deviations $(n=6)$. Columns with different letters are statistically different $(p<0.05)$.

\subsection{Changes in the Quantum Yields and the Fraction of Open Photosystem II Reaction Centers after Cadmium Exposure under Low Light}

The quantum efficiency of PSII photochemistry $\left(\Phi_{P S I I}\right)$ measured at low light (LL, $220 \mu \mathrm{mol}$ photons $\left.\mathrm{m}^{-2} \mathrm{~s}^{-1}\right)$ (Figure 5a) increased $(p<0.05)$ in S. sclarea plants exposed to $C d$ stress for 2 and 5 days compared to their respective controls, indicating a higher fraction of absorbed light energy to be directed to photochemistry under Cd stress. The 
concomitant increase in the quantum yield of regulated heat dissipation in PSII $\left(\Phi_{N P Q}\right)$ (Figure 5b) under 2- and 5-days Cd stress resulted in a significant decrease in the quantum yield of non-regulated energy dissipated in PSII ( $\Phi_{N O}$ ) (Figure $5 c$ ), indicating a better use of the absorbed light energy in S. sclarea Cd stressed plants. The fraction of open PSII reaction centers $\left(q_{\mathrm{P}}\right)$, at LL (Figure $\left.5 \mathrm{~d}\right)$ ), increased $(p<0.05)$ in $S$. sclarea plants exposed to $\mathrm{Cd}$ stress for 2 days, while at 5 days exposure remain the same, compared to controls.
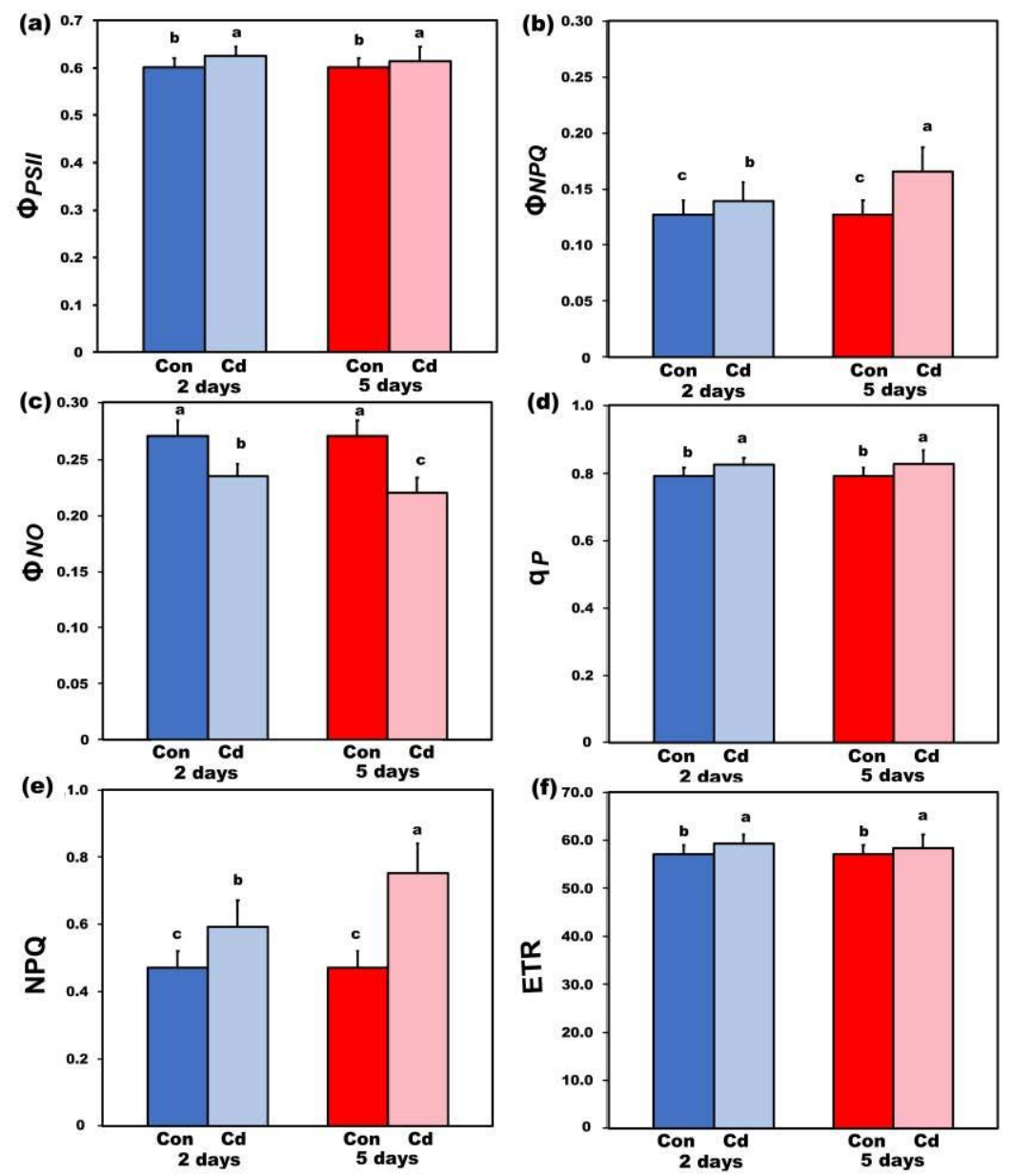

Figure 5. Changes in the quantum efficiency of PSII photochemistry $\left(\Phi_{P S I I}\right)(\mathbf{a})$, the quantum yield of regulated heat dissipation in PSII $\left(\Phi_{N P Q}\right)(\mathbf{b})$, the quantum yield of non-regulated energy dissipated in PSII $\left(\Phi_{N O}\right)(\mathbf{c})$, the fraction of open PSII reaction centers $\left(q_{\mathrm{P}}\right)(\mathbf{d})$, the non-photochemical quenching (NPQ) (e) and the electron transport rate (ETR) (f), measured at $220 \mu \mathrm{mol}$ photons $\mathrm{m}^{-2} \mathrm{~s}^{-1}$; of control (con) and 2- and 5-days Cd-treated Salvia sclarea plants. Error bars are standard deviations $(n=6)$. Columns with different letters are statistically different $(p<0.05)$.

\subsection{Changes in Non-Photochemical Fluorescence Quenching and Electron Transport Rate after Cadmium Exposure under Low Light}

Non-photochemical quenching (NPQ) increased $(p<0.05)$ in plants exposed to Cd stress for 2 and 5 days compared to their respective controls (Figure 5e). Electron transport rate measured at $220 \mu \mathrm{mol}$ photons $\mathrm{m}^{-2} \mathrm{~s}^{-1}$ (Figure $5 \mathrm{f}$ ) increased $(p<0.05)$ in $S$. sclarea plants exposed to $\mathrm{Cd}$ stress for 2 and 5 days compared to their respective controls, following the pattern of $\Phi_{P S I I}$ (Figure 5a).

\subsection{Changes in Excess Excitation Energy under Low and High Light after Cadmium Exposure}

The excess excitation energy (EXC) at PSII in S. sclarea, at $220 \mu \mathrm{mol}$ photons $\mathrm{m}^{-2} \mathrm{~s}^{-1}$ (LL) after 2 days Cd exposure, decreased $(p<0.05)$ compared to control, while, after 5 days $\mathrm{Cd}$ exposure, it was at the same level with control (Figure 6a). However, under high 
light (HL, $900 \mu \mathrm{mol}$ photons $\left.\mathrm{m}^{-2} \mathrm{~s}^{-1}\right)$ after 5 days Cd exposure, EXC increased $(p<0.05)$ compared to control (Figure 6b), indicating that the synergistic effect of $\mathrm{Cd}$ stress and HL resulted in a lower efficiency of light energy use by PSII.
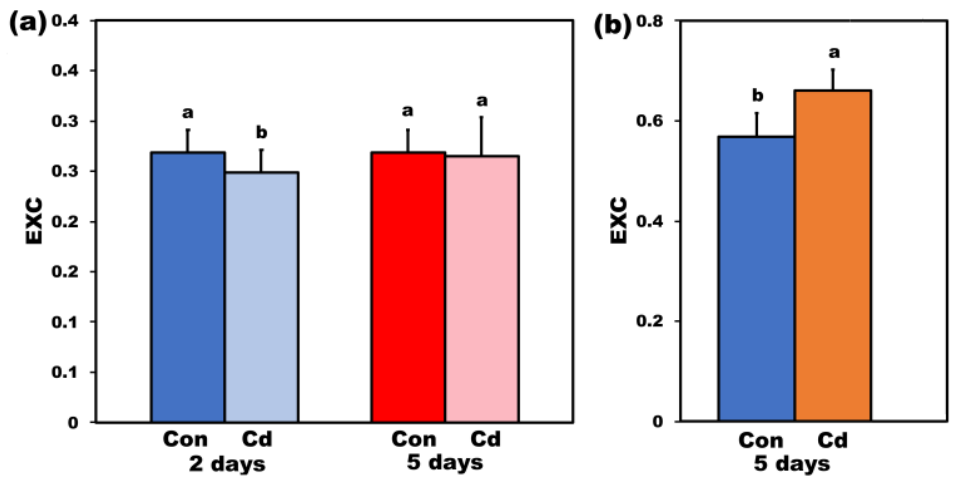

Figure 6. Changes in the excess excitation energy (EXC) measured at $220 \mu \mathrm{mol}$ photons $\mathrm{m}^{-2} \mathrm{~s}^{-1}$ of control (con) and2- and 5-days Cd-treated Salvia sclarea plants (a) and the EXC measured at $900 \mu \mathrm{mol}$ photons $\mathrm{m}^{-2} \mathrm{~s}^{-1}$ of control (con) and 5 days Cd-treated $S$. sclarea plants (b). Error bars are standard deviations $(\mathrm{n}=6)$. Columns with different letters are statistically different $(p<0.05)$.

\subsection{Changes in the Quantum Yields under High Light after Cadmium Exposure}

The allocation of absorbed light energy to PSII photochemistry $\left(\Phi_{\text {PSII }}\right)$ measured at $\mathrm{HL}$ in S. sclarea plants exposed to Cd for 5 days decreased $(p<0.05)$ compared to controls, while the regulated heat dissipation $\left(\Phi_{N P Q}\right)$ increased $(p<0.05)$ in such a degree that the non-regulated energy dissipation $\left(\Phi_{N O}\right)$ in S. sclarea plants exposed to $\mathrm{Cd}$ for 5 days did not differ compared to controls (Figure 7).

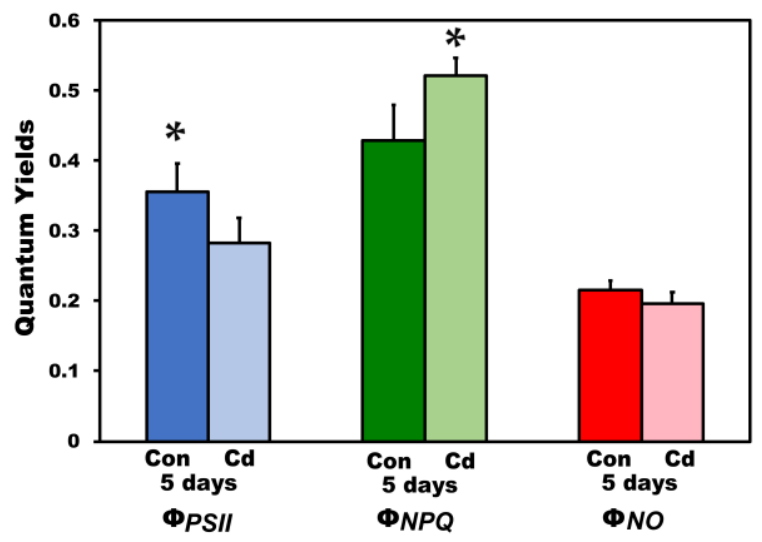

Figure 7. The quantum yields of PSII photochemistry $\left(\Phi_{P S I I}\right)$, the regulated heat dissipation $\left(\Phi_{N P Q}\right)$, and the non-regulated energy dissipation $\left(\Phi_{N O}\right)$, measured at $900 \mu \mathrm{mol}$ photons $\mathrm{m}^{-2} \mathrm{~s}^{-1}$; of control (con) and 5 days Cd-treated Salvia sclarea plants. Error bars are standard deviations $(n=6)$. Means between the two treatments that are statistically different $(p<0.05)$ are marked by an asterisk $\left(^{*}\right)$.

2.8. Changes in Non-Photochemical Fluorescence Quenching, Electron Transport Rate, and the Fraction of Open Photosystem II Reaction Centers under High Light after Cadmium Exposure

Non-photochemical quenching (NPQ), measured at HL, increased $(p<0.05)$ in S. sclarea plants exposed for 5 days to Cd compared to control plants (Figure 8a), while PSII electron transport rate decreased $(p<0.05)$ compared to controls (Figure $8 \mathbf{b}$ ), following the pattern of $\Phi_{\text {PSII }}$ (Figure 7). The fraction of open PSII reaction centers $\left(q_{\mathrm{P}}\right)$ decreased $(p<0.05)$ in S. sclarea plants exposed for 5 days to Cd compared to control plants (Figure 8c). 

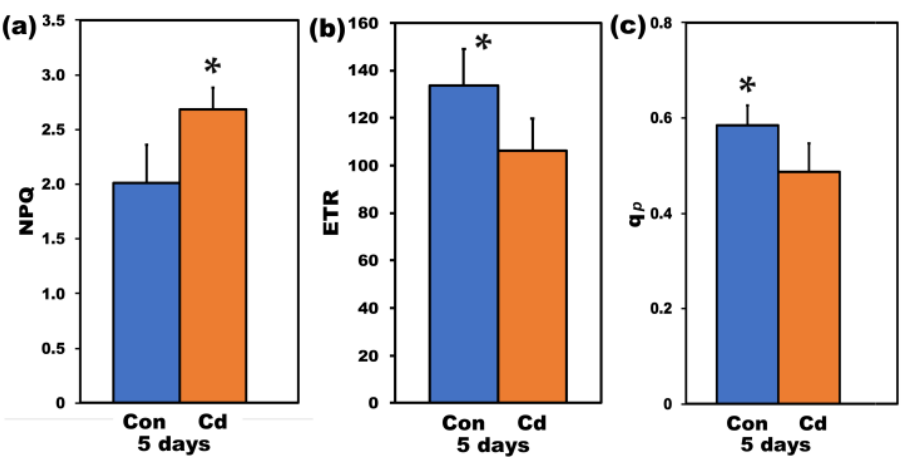

Figure 8. The non-photochemical fluorescence quenching (NPQ) (a), the relative PSII electron transport rate (ETR) (b), and the relative reduction state of $Q_{A}$, reflecting the fraction of open PSII reaction centers $\left(q_{\mathrm{P}}\right)(\mathrm{c})$, measured at $900 \mu \mathrm{mol}$ photons $\mathrm{m}^{-2} \mathrm{~s}^{-1}$; of control (con) and 5 days Cdtreated Salvia sclarea plants. Error bars are standard deviations $(n=6)$. Means between the two treatments that are statistically different $(p<0.05)$ are marked by an asterisk $\left(^{*}\right)$.

\subsection{Chlorophyll a Fluorescence Images under Low and High Light}

Chlorophyll $a$ fluorescence images of the fluorescence parameters $\Phi_{P S I I}$ and $\Phi_{N O}$, measured at LL and HL, of control and 5 days Cd-treated S. sclarea plants, revealed a spatial heterogeneity over the whole leaf area (Figure 9). The heterogeneity was higher under $\mathrm{Cd}$ exposure with $\Phi_{P S I I}$ values at the center of the leaf and near the main leaf vein to have lower values compared to marginal, while the spatial heterogeneity was even higher under HL and Cd exposure (Figure 9).

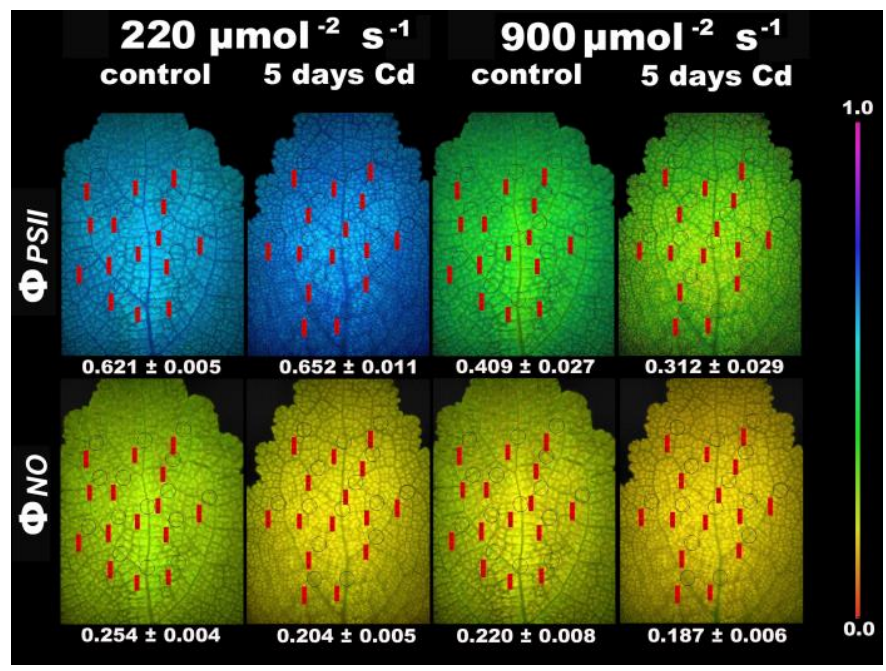

Figure 9. Chlorophyll fluorescence images of $\Phi_{P S I I}$ and $\Phi_{N O}$ (measured at $220 \mu \mathrm{mol}$ photons $\mathrm{m}^{-2} \mathrm{~s}^{-1}$ and $900 \mu \mathrm{mol}$ photons $\mathrm{m}^{-2} \mathrm{~s}^{-1}$ ) of control and 5 days Cd-treated Salvia sclarea plants. The color code depicted at the right-side ranges from values 0.0 to 1.0. The fifteen circles in each image denote the areas of interest (AOI) that are complemented by red labels with the values of the fluorescence parameter, while whole leaf value is presented.

The effective quantum yield of PSII photochemistry $\left(\Phi_{P S I}\right)$ after 5 days Cd exposure, was higher under LL compared to control, but it was lower under HL compared to control (Figure 9). The non-regulated energy loss in PSII $\left(\Phi_{N O}\right)$, under both LL and HL, was lower in 5 days Cd-treated S. sclarea plants compared to controls (Figure 9). At longer duration exposure (8 days) to Cd under LL, the inhibition of PSII functionality that was observed (Figure 10) resulted in the reduction of whole plant biomass by $18 \%(p<0.05)$. At 8 days exposure of $S$. sclarea plants to $\mathrm{Cd}$, the lowest $\mathrm{Fv} / \mathrm{Fm}$ values were found near the midvein, while the lowest $\Phi_{P S I I}$ values were at the half leaf area near the base (Figure 10). 


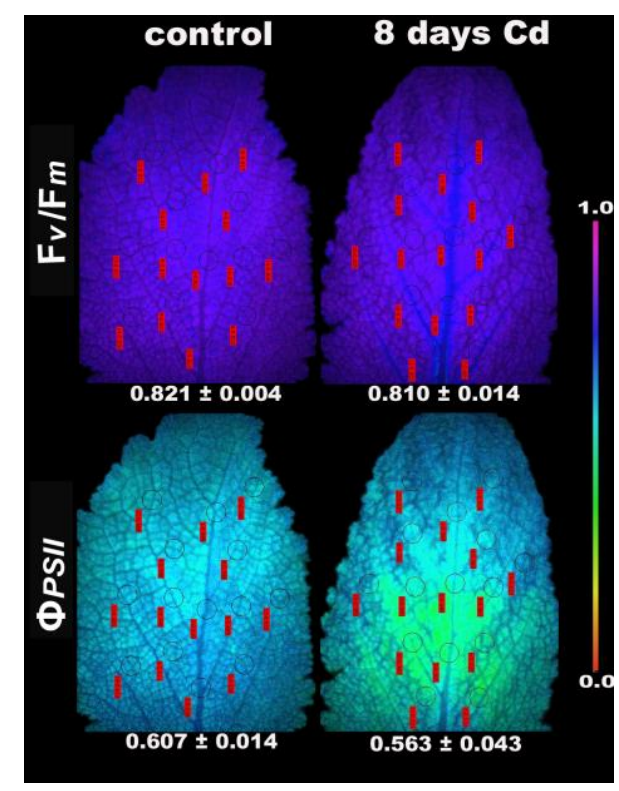

Figure 10. Representative chlorophyll fluorescence images of the maximum efficiency of PSII photochemistry $(\mathrm{Fv} / \mathrm{Fm})$, and the effective quantum yield of PSII photochemistry $\left(\Phi_{P S I I}\right)$ (measured at $220 \mu \mathrm{mol}$ photons $\mathrm{m}^{-2} \mathrm{~s}^{-1}$ ), of $S$. sclarea leaves from control and 8 days Cd-treated plants. The color code depicted at the right-side ranges from values 0.0 to 1.0. The fourteen circles in each image are the areas of interest (AOI) complemented by red labels with the values of the fluorescence parameter. The average value of each photosynthetic parameter of the whole leaf is presented.

\subsection{Lipid Peroxidation and Hydrogen Peroxide $\left(\mathrm{H}_{2} \mathrm{O}_{2}\right)$ after Cadmium Exposure}

The final product of lipid peroxidation, malondialdehyde (MDA) content (Figure 11b), increased with increased exposure time to $\mathrm{Cd}$. The same pattern was observed in $\mathrm{H}_{2} \mathrm{O}_{2}$ generation (Figure 11a).
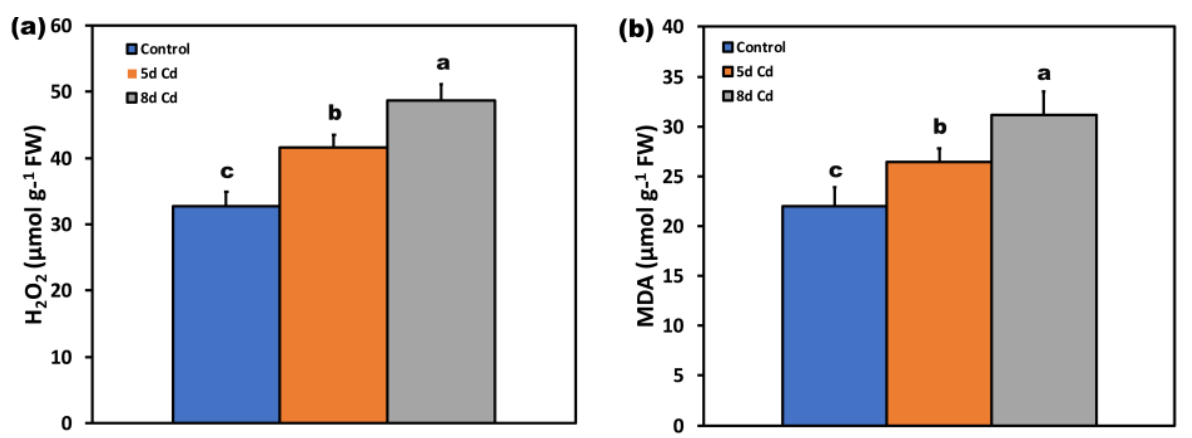

Figure 11. Changes in hydrogen peroxide $\left(\mathrm{H}_{2} \mathrm{O}_{2}\right)$ generation $(\mathbf{a})$, and lipid peroxidation production (b), in the leaves of Salvia sclarea control (con), and 5- and 8-days Cd-treated plants. Error bars are standard deviations $(n=6)$. Columns with different letters are statistically different $(p<0.05)$.

This trend was also obvious in the histochemically detected $\mathrm{H}_{2} \mathrm{O}_{2}$ production of Salvia sclarea leaves (Figure 12). After 5 days exposure to $\mathrm{Cd}$, the increased $\mathrm{H}_{2} \mathrm{O}_{2}$ production was detected mainly in the leaf midveins near the basal leaf area, while after 8 days exposure, the highly increased $\mathrm{H}_{2} \mathrm{O}_{2}$ was not identified in the midveins but it was noticed to spread to the whole leaf (Figure 12). 


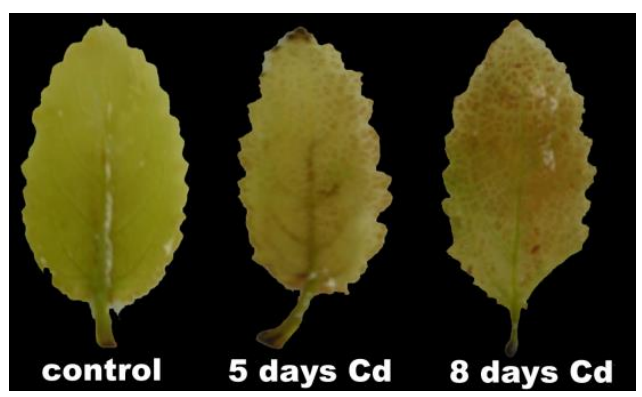

Figure 12. Histochemically detected $\mathrm{H}_{2} \mathrm{O}_{2}$ in leaves of Salvia sclarea, control, and 5- and 8-days Cdtreated plants. Hydrogen peroxide is forming brown precipitates with 3,3'-diaminobenzidine (DAB).

\subsection{Chloroplast Ultrastructure after Cadmium Exposure}

Leaves from control plants exhibited rather electronically dense mesophyll chloroplasts (Figure 13a) that showed a typical internal membrane structure with well-organized grana and stroma thylakoids (Figure 13a). Chloroplasts, in both 2 days (Figure 13b) and 5 days (Figure 13c) Cd-treated plants, did not show any noticeable structural disruption having a similar appearance to the control, with the 5 day Cd-treated plastids to appear more electronically dense (Figure 13c). However, after 8 days exposure to $\mathrm{Cd}$, chloroplasts appeared even more electronically dense and their thylakoids were swollen (Figure S1b). In control, 2 days and 5 days Cd-treated plants, starch grains were noticeable in chloroplasts, which were absent in 8 days Cd-treated chloroplasts (Figure S1b).
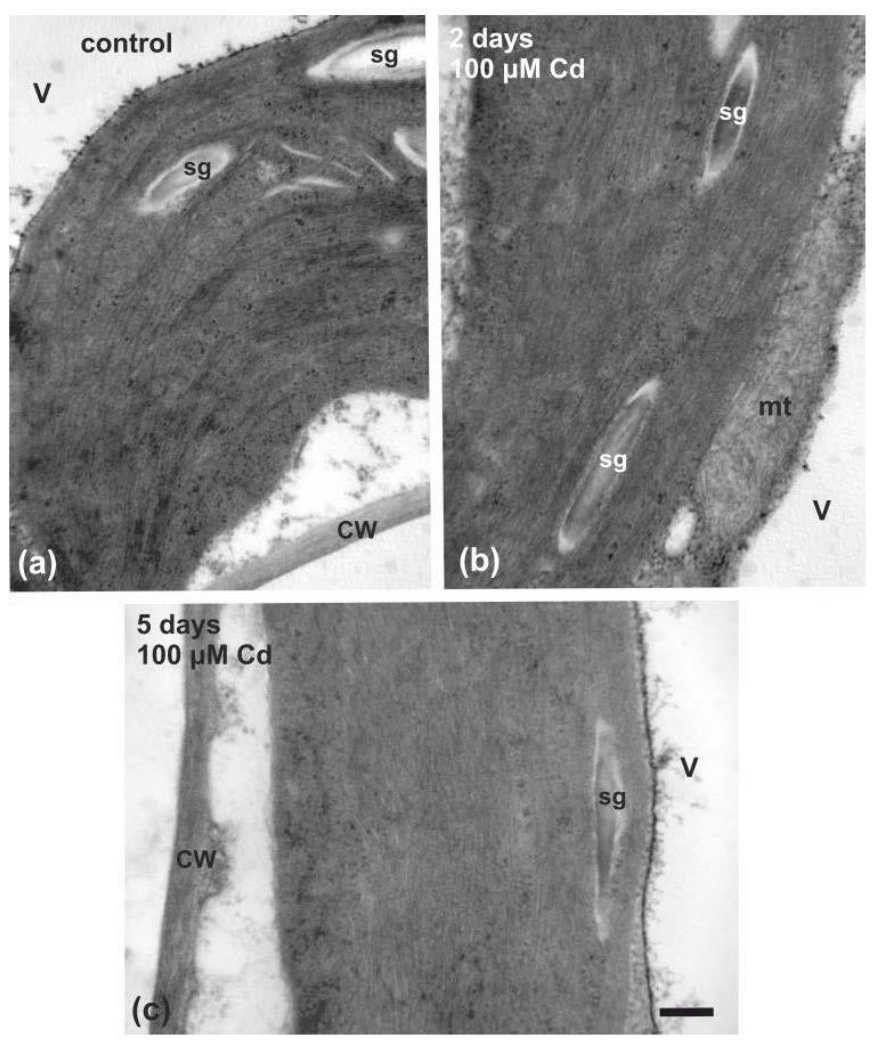

Figure 13. Transmission electron microscopy (TEM) images of control (untreated) chloroplasts (a) and 2 day $(\mathbf{b})$, or 5 day $(\mathbf{c})$, Cd-treated Salvia sclarea leaves. Chloroplasts appear electronically dense and upon $\mathrm{Cd}$ treatment $(\mathbf{b}, \mathbf{c})$, no noticeable disruption has been detected. $\mathrm{cw}$ : cell wall; $\mathrm{mt}$ : mitochondria; sg: starch grain; v: vacuole. Scale bar: $500 \mathrm{~nm}$. 


\section{Discussion}

Exposure of S. sclarea plants to $100 \mu \mathrm{M}$ Cd for 5 days in hydroponics resulted in a high Cd uptake with a 2400-fold increase at the whole plant level but with Cd ions to be retained almost exclusively in the roots (Figure $1 \mathrm{~b}$ ) and only $53.3 \mu \mathrm{g} \mathrm{g}^{-1}$ to be translocated to the aboveground tissues (Figure 1a). Low $\mathrm{Cd}$ accumulation in leaves may represent a tolerance mechanism that protects the photosynthetic equipment against additional oxidative stress [48-50]. In the tolerant plant species, the excess heavy metals in roots play a significant role by sequestrating and detoxifying the extreme amount of heavy metal in order to protect the delicate aboveground photosynthetic tissues [51,52]. Since leaf $\mathrm{Cd}$ contents greater than 5-10 $\mu \mathrm{g} \mathrm{g}^{-1}$ have been characterized toxic to most plants [53-55], it seems that $S$. sclarea could have kept $\mathrm{Cd}$ concentration in the photosynthetic tissues in non-toxic forms. This could be done by depositing it in the vacuoles of leaf epidermal cells [56] and/or by complexation with cellular ligands [7,55-57]. Hyperaccumulators can accumulate $\mathrm{Cd}$ to levels above $100 \mu \mathrm{g} \mathrm{g}^{-1}$ of shoot dry weight, without showing any toxicity symptoms [7,58]. Our results agree with those of He et al. [59] that roots of Cd tolerant plants (non-hyperaccumulators) retain considerably higher $\mathrm{Cd}$ concentrations than the aboveground parts, and only minor $\mathrm{Cd}$ is translocated to the aerial parts. In comparison to the above-ground tissues, $S$. sclarea roots showed a higher bioaccumulation ability of $\mathrm{Cd}$ with translocation to shoots-leaves to be restricted.

Cadmium uptake is affected by Ca levels because $\mathrm{Cd}$ competes for $\mathrm{Ca}$ channels $[7,60,61]$ and the low $\mathrm{Ca}$ content of the hydroponic solution may enhance $\mathrm{Cd}$ uptake [62], resulting in enhanced $\mathrm{Cd}$ and decreased $\mathrm{Ca}$ in many plant species [7,61], as we also observed in S. sclarea experiments, with Ca being the most affected element (58\% total uptake decrease, Figure 2e). Likewise, in Oryza sativa seedlings exposed to Cd, uptake of Ca was decreased, and Ca content in both roots and aboveground parts was significantly reduced [63]. Magnesium was the next most negatively affected element after Ca in our experiments, but low $\mathrm{Mg}$ status has been associated with increased Cd tolerance [64-68], indicating that plants regulate nutrient concentrations to mitigate $\mathrm{Cd}$ toxicity [68].

Antagonistic effects of Cd with Fe [50,61,69] and Zn [57,70] have been frequently reported. However, in S. sclarea exposed to $100 \mu \mathrm{M} \mathrm{Cd}$ for 5 days, total $\mathrm{Zn}, \mathrm{Cu}$, and $\mathrm{Fe}$ uptake increased but their translocation to the aboveground parts decreased possible due to translocation barriers. It seems that $\mathrm{Cd}$ uptake in S. sclarea is not taking place through the Fe or Zn pathway, while conditions that lead to increased Cd uptake in plants may also favor increased Fe uptake [7]. Cd treatment has been frequently mentioned that it increases Fe retention in roots but obstructs its translocation to shoots, thus reducing Fe concentrations in aboveground parts [59,71,72]. In rice, $\mathrm{Cd}$ has been shown to be taken up predominantly via the Mn pathway $[73,74]$ but this was not the case in S. sclarea, since Mn was the less negatively affected element.

Cadmium contamination of soil has become a serious environmental alarm as it is estimated that around 30,000 $\mathrm{t}$ of $\mathrm{Cd}$ is released annually into the environment with a consequence to the food chain and a threat to human health [75]. The use of plants for heavy metals elimination from pollutant soils and water is a technique known as phytoremediation [76]. In phytoremediation, plants that absorb heavy metals from soils and translocate them to the harvestable shoots are used for phytoextraction, while those that stabilize metal contaminants through accumulation in the root zones are used for phytostabilization $[75,77]$. Plant species with high bioconcentration factor but relatively low translocation factor $(<1)$ may be considered as potential phytostabilizers [78]. Salvia sclarea exhibited high accumulation capacity for $\mathrm{Cd}$, and by limiting its translocation from roots to shoots, it may be considered a potential phytostabilizer that can be used in heavy metal contaminated environments. Other plant species that have been proposed as $\mathrm{Cd}$ phytostabilizers are Iris lactea [75] and Sesuvium portulacastrum [79,80].

Despite the significant levels of $\mathrm{Cd}$ in leaves, a higher fraction of absorbed light energy was directed to photochemistry $\left(\Phi_{P S I I}\right)$ under 2 - and 5-days $C d$ stress, with a concomitant increase in $\Phi_{N P Q}$ that resulted in a significant decrease in $\Phi_{N O}$ (Figure 5). The 
non-regulated energy loss in PSII $\left(\Phi_{N O}\right)$ encompasses internal conversions and intersystem crossing, which results in singlet oxygen $\left({ }^{1} \mathrm{O}_{2}\right)$ creation via the triplet state of chlorophyll $\left({ }^{3} \mathrm{Chl}^{*}\right)$ [29,81-83]. To optimize photosynthesis and growth under stressful conditions, plants have evolved a variety of mechanisms against photodamage and photoinhibition $[84,85]$. Non-photochemical quenching is the key photoprotective process that dissipates excess light energy as heat and protects photosynthesis [81,86-90]. Thus, the increased nonphotochemical quenching of photosynthesis (NPQ) altered ROS homeostasis through a decreased ${ }^{1} \mathrm{O}_{2}$ formation. Consequently, in $S$. sclarea plants exposed to $100 \mu \mathrm{M} \mathrm{Cd}$, ROS homeostasis could be regulated by NPQ in such a way so that plants can cope with $\mathrm{Cd}$ stress $[19,22,26,27]$.

The potential PSII efficiency of S. sclarea plants exposed to $100 \mu \mathrm{M}$ Cd estimated by the maximum efficiency of PSII photochemistry (Fv/Fm) (Figure 4a) and the efficiency of the water-splitting complex on the donor side of PSII (Fv/Fo) (Figure 4b) [29,91] indicated an enhanced PSII functionality under Cd stress. In accordance, S. sclarea plants exposed to $100 \mu \mathrm{M}$ Cd show an increased capacity to keep quinone (QA) oxidized, thus, to have a higher fraction of open PSII reaction centers $\left(q_{\mathrm{P}}\right)$ compared to controls (Figure $5 \mathrm{~d}$ ). In other words, S. sclarea plants exposed to $100 \mu \mathrm{M}$ Cd show a low PSII excitation pressure associated with toxicity tolerance mechanisms [92,93]. High excitation pressure defines excess energy and consequently a disproportion between energy resource and requirement [94]. This discrepancy leads to an increase in the energy transmitted from chlorophyll to oxygen, resulting in ${ }^{1} \mathrm{O}_{2}$ generation [95]. Control $S$. sclarea plants that show increased excess excitation energy (EXC) at PSII (Figure 6a), show also increased ${ }^{1} \mathrm{O}_{2}$ creation via ${ }^{3} \mathrm{chl}^{*}$, compared to plants exposed to $\mathrm{Cd}$ for 2 days (Figure $5 \mathrm{c}$ ). In contrast to ${ }^{1} \mathrm{O}_{2}$ generation that decreased under 2 and 5 days $\mathrm{Cd}$ exposure (Figure $5 \mathrm{c}$ ), $\mathrm{H}_{2} \mathrm{O}_{2}$ production after 5 days $\mathrm{Cd}$ exposure increased compared to control (Figure 11a), being detected mainly in the leaf midveins near the basal leaf area (Figure 12), while after 8 days exposure, increased more (Figure 11a) and was noticed to spread to the whole leaf (Figure 12). Thus, since ROS are formed by energy transfer $\left({ }^{1} \mathrm{O}_{2}\right)$ and electron transport $\left(\mathrm{H}_{2} \mathrm{O}_{2}\right)$ simultaneously, it appears likely that their action interferes with the signaling pathways sometimes to antagonize each other. It has been frequently shown that hydrogen peroxide disperses through leaf veins to act as a long-distance molecule, triggering the stress defence response in plants $[20,25,27,83,89]$.

A basal level of ROS is needed for optimal growth (control) [20,25], with a low increased level of ROS to be beneficial for triggering defense responses ( 5 days Cd exposure), and a high level of ROS ( 8 days Cd exposure) to be out of the boundaries and harmful to plants [20,34]. Photosystem II responses to short time Cd exposure of S. sclarea can be described as a hormetic response (Figure 14), representing an "over-compensation" response to a disruption in homeostasis [42].

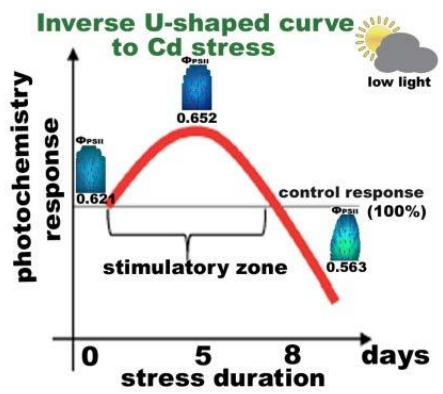

Figure 14. Overview of the hormetic response of photosystem II photochemistry to Cd exposure. Hormesis [96] is defined as the stimulatory effect of short exposure times of toxic constituents, e.g., $\mathrm{Cd}$ on a biological factor (photosystem II photochemistry), of a particular organism (S. sclarea). The hormetic effect is defined by an inverse U-shaped biphasic curve $[8,34]$ in which short exposure time has a stimulatory effect; however, at longer exposure time, a toxic effect is evident. 
Although excess $\mathrm{Cd}$ accumulation is detrimental to plants, different strategies of $\mathrm{Cd}$ tolerance and accumulation are adopted by plants [97]. Tang et al. [98] described a stimulation of plant growth, increase of photosynthesis, and an up-regulation of the related genes in Sedum alfredii exposed to $5 \mu \mathrm{M} \mathrm{Cd}$. Similar results with stimulation of growth when Noccea caerulescens was exposed to $100 \mu \mathrm{M} \mathrm{Cd}$ were reported by Lombi et al. [99]. A stimulatory effect of $\mathrm{Cd}$ on the photosynthetic apparatus of Arabidopsis halleri was also described recently [33]. Małkowski et al. [36] reported a stimulation of the photosynthetic rate by $\mathrm{Cd}$ only at low concentrations, whereas at higher $\mathrm{Cd}$ concentrations, there was a significant decrease compared to controls. Nevertheless, other studies have shown a dose dependent negative impact of $\mathrm{Cd}$ that increases with the generation of ROS and oxidative damage and the inhibition of photosynthetic rate to follow [5,100-106]. On the other hand, protection to stress through ROS production $[25,107]$ has been shown that it can be regulated by NPQ in such a way so that plants can cope with stress [22,26,27].

A negative impact of $\mathrm{Cd}$ on photosynthesis has been assigned to decreases in chlorophylls; ascribed to Cd-induced damage in chloroplasts' ultrastructure [108,109]. However, in our experiment, the significant chlorophyll content decreases in $S$. sclarea leaves exposed to $\mathrm{Cd}$ for 2 and 5 days (Figure $3 \mathrm{a}$ ) cannot be attributed to chloroplasts' ultrastructure destruction but rather to the significantly decreased $\mathrm{Mg}$ uptake (Figure 2f). However, $\mathrm{Mg}$ content in the leaves after 5 days $\mathrm{Cd}$ exposure $\left(2778 \pm 83 \mu \mathrm{g} \mathrm{g}^{-1}\right)$ remained higher than the adequate range limit $\left(2000 \mu \mathrm{g} \mathrm{g}^{-1}\right)$ [110].

Cadmium has been reported to alter chloroplast ultrastructure, reduce photosynthesis [68,106,111], and inactivate enzymes involved in $\mathrm{CO}_{2}$ fixation [60]. Ultrastructural changes that are observed in $\mathrm{Cd}$ exposed leaves of sensitive plants (thylakoid dismantling, increase of lipid droplets, etc.) [112-115] are similar to those occurring at leaf ageing [116]. In Cd tolerant species, the only ultrastructural alteration observed in leaves was a reduction of starch grains in chloroplasts $[50,102,117]$, which may be due to disorders in the photoassimilate transport or to nutrient deficiency $[50,118]$, a phenomenon also observed after 8 days exposure to Cd (Figure S1). In S. sclarea Cd-treated plants, an increase in deposited electron-dense material was observed, as reported also by Mizushima et al. [50], but no other noticeable alteration in 2- and 5-days Cd-treated plastids was detected, further consolidating the chlorophyll fluorescence imaging results. Thus, a hormetic response of PSII photochemistry to short term Cd exposure was observed, indicating an "over-compensation" response to Cd disruption in homeostasis, justifying the statement of Carvalho et al. [8] that $\mathrm{Cd}$ can be regarded from a toxic element, a beneficial one. Hormesis research data and data on priming (preconditioning), an expression of hormesis [16,34,119-121], indicate that stimulatory response detection of the low-dose or short-time exposure is highly dependent on the study strategy, including dose range and the number with duration exposure and endpoint selected $[13,14,16,34,52]$.

Exposure of S. sclarea plants to a combination of Cd and high light $(900 \mu \mathrm{mol}$ photons $\mathrm{m}^{-2} \mathrm{~s}^{-1}$ ) resulted in an inhibition of PSII functionality (Figures 7 and 9), while the increased NPQ (Figure 8a) was inefficient to keep the same number of open reaction centers PSII $\left(q_{\mathrm{P}}\right.$, Figure $\left.8 \mathrm{c}\right)$ compared to control plants. Dissipation of excess light energy as heat (NPQ) under environmental pressure conditions is effective only if it is regulated so as to maintain the same fraction of open reaction centers as in unstressed conditions [88,89,122-125], as was observed under low light exposure of $S$. sclarea plants to $\mathrm{Cd}$, with even an increased fraction of open reaction centers to occur (Figure 5d). Thus, the combination of $\mathrm{Cd}$ and high light points out to $\mathrm{Cd}$ toxicity. The same conclusion is reached [126] at longer duration exposure (8 days) to Cd at LL, with an inhibition of PSII functionality to be observed (Figure 10).

\section{Materials and Methods}

\subsection{Plant Material and Growth Conditions}

Seeds of Salvia sclarea L. used for the experiments were collected from the Rose Valley (Karlovo, Bulgaria). After germination on soil in a growth room for about a month, the 
seedlings were transferred to pots containing continuously aerated modified Hoagland nutrient solution (described in detail before) [6]. The nutrient solution was adjusted to $\mathrm{pH} 6.0$ and changed every 3 days. The growth room conditions were $24 \pm 1 / 20 \pm 1{ }^{\circ} \mathrm{C}$ day/night temperature, $14 / 10 \mathrm{~h}$ day/night photoperiod with photon flux density $200 \pm 20 \mu \mathrm{mol}$ photons $\mathrm{m}^{-2} \mathrm{~s}^{-1}$.

\subsection{Cadmium Treatment}

Two-month-old $S$. sclarea plants in the hydroponic culture experiments were subjected to 0 or $100 \mu \mathrm{M} \mathrm{Cd}$ (as $3 \mathrm{CdSO}_{4} 8 \mathrm{H}_{2} \mathrm{O}$ ) for a period up to five days. The pots containing only Hoagland nutrient solution served as the control, while all solutions were renewed every two days.

\subsection{Determination of Elemental Concentration by Inductively Coupled Plasma Mass Spectrometry (ICP-MS)}

After 5 days treatment with 0 (control) or $100 \mu \mathrm{M} \mathrm{Cd}$, Salvia plants were harvested, separated in roots and aboveground (shoots-leaves) tissues, washed three times in deionized water, and then dried at $65{ }^{\circ} \mathrm{C}$ to constant biomass, milled and finally sieved. Dried sieved samples of $0.3 \mathrm{~g}$ were transferred in $10 \mathrm{~mL}$ quartz vessels with $65 \%(\mathrm{v} / \mathrm{v})$ nitric acid (Suprapur, Merck, Darmstadt, Germany) and 30\% (v/v) hydrogen peroxide (Suprapur, Merck, Darmstadt, Germany) in 3:1 ratio. Digestion was carried out in the microwave assisted digestion system Ethos One (Milestone Srl, Sorisole, BG, Italy). The process run out in 3 stages: ramp time $-20 \mathrm{~min}$ to reach $200{ }^{\circ} \mathrm{C}$ and $1500 \mathrm{~W}$; hold time-30 min at $200{ }^{\circ} \mathrm{C}$ and $1500 \mathrm{~W}$; cooling-30 min. The next step was the quantitative transfer of digested samples into polypropylene tubes and dilution with demineralized water (Direct-Q 3 UV, Merck, Darmstadt, Germany). All prepared samples were diluted immediately prior to inductively coupled plasma mass spectrometer (ICP-MS) analysis. Samples were analyzed in an ICP-MS model ELAN DRC II (PerkinElmer Sciex, Toronto, Canada) [127]. ICP-MS operational conditions, instrumental settings calibration solutions, data validation, and validation parameters are given in Appendix A. Elemental analysis was performed for $\mathrm{Cd}$, $\mathrm{Cu}, \mathrm{Ca}, \mathrm{Mg}, \mathrm{Mn}, \mathrm{Fe}$, and $\mathrm{Zn}$.

\subsection{Measurements of Chlorophyll $a$ and Chlorophyll $b$ Content}

Chlorophyll $a(\mathrm{Chl} a)$ and chlorophyll $b(\mathrm{Chl} b)$ content was determined according to Lichtenthaler [128]. Leaf tissue (50 mg) was homogenized with $10 \mathrm{~mL}$ ice-cold 80\% (v/v) acetone and centrifuged at $5000 \times g$ for $5 \mathrm{~min}$ at $4{ }^{\circ} \mathrm{C}$. The absorbance of the supernatant was measured at 646.8 and $663.2 \mathrm{~nm}$ (Specord 210 Plus, Ed. 2010, Analytik Jena AG, Jena, Germany) and Chl $a$ and $\mathrm{Chl} b$ content was estimated from the equations: Chl $a=12.25 \mathrm{~A}_{663.2}$ $-2.79 \mathrm{~A}_{646.8} ; \mathrm{Chl} b=21.50 \mathrm{~A}_{646.8}-5.10 \mathrm{~A}_{663.2}$ [128]. The mean values were averaged from three independent treatments with 2 repetitions for each treatment and are presented as $\mathrm{mg} \mathrm{g}^{-1} \mathrm{FW}$.

\subsection{Chlorophyll Fluorescence Imaging Analysis}

Chlorophyll fluorescence measurements were conducted on dark adapted (20 min) leaves of S. sclarea plants, treated for 2 and 5 days with 0 (control) or $100 \mu \mathrm{M} \mathrm{Cd}$, using an Imaging PAM M-Series system (Heinz Walz Instruments, Effeltrich, Germany) as described in detail previously [129]. Two light intensities were used for measurements of photosynthetic efficiency of $S$. sclarea leaves, a LL, similar to the growth light $(220 \mu \mathrm{mol}$ photons $\left.\mathrm{m}^{-2} \mathrm{~s}^{-1}\right)$, and a HL $\left(900 \mu \mathrm{mol}\right.$ photons $\left.\mathrm{m}^{-2} \mathrm{~s}^{-1}\right)$. In each leaf, representative areas of interest (AOIs) were selected so as to have measurements of the whole leaf area. The definitions of the five main chlorophyll fluorescence parameters (Fo, Fm, Fo', Fm', and Fs) measured by the Imaging PAM M-Series system are presented in Table S1, while a typical modulated fluorescence trace showing how the main five parameters are formed is presented in Figure S2. The chlorophyll fluorescence parameters calculated from the five main parameters with their definitions are described in Table 1. Representative results are also shown as color-coded images of Fv/Fm after dark adaptation and of $\Phi_{P S I I}$ 
and $\Phi_{N O}$, after 5 min illumination with $220 \mu \mathrm{mol}$ photons $\mathrm{m}^{-2} \mathrm{~s}^{-1}$ (LL) or/and $900 \mu \mathrm{mol}$ photons $\mathrm{m}^{-2} \mathrm{~s}^{-1}$ (HL).

Table 1. Definitions of the chlorophyll fluorescence parameters calculated from the five main chlorophyll fluorescence parameters listed in Table S1.

\begin{tabular}{|c|c|c|}
\hline Parameter & Definition & Calculation \\
\hline $\mathrm{Fv} / \mathrm{Fm}$ & Maximum efficiency of PSII photochemistry & Calculated as $(\mathrm{Fm}-\mathrm{Fo}) / \mathrm{Fm}$ \\
\hline $\mathrm{Fv} / \mathrm{Fo}$ & $\begin{array}{c}\text { Efficiency of the water-splitting complex on the donor } \\
\text { side of PSII }\end{array}$ & Calculated as $(\mathrm{Fm}-\mathrm{Fo}) / \mathrm{Fo}$ \\
\hline $\mathrm{F} v^{\prime} / \mathrm{F} m^{\prime}$ & The efficiency of open PSII reaction centers & Calculated as $\left(\mathrm{Fm}^{\prime}-\mathrm{Fo}^{\prime}\right) / \mathrm{Fm}^{\prime}$ \\
\hline$\Phi_{\text {PSII }}$ & The effective quantum yield of PSII photochemistry & Calculated as $\left(\mathrm{Fm}^{\prime}-\mathrm{Fs}\right) / \mathrm{Fm}^{\prime}$ \\
\hline$q_{\mathrm{p}}$ & $\begin{array}{l}\text { The photochemical quenching, that is the redox state of } \\
\text { the plastoquinone pool, is a measure of the number of } \\
\text { open PSII reaction centers }\end{array}$ & Calculated as $\left(\mathrm{Fm}^{\prime}-\mathrm{Fs}\right) /\left(\mathrm{Fm}^{\prime}-\mathrm{Fo}^{\prime}\right)$ \\
\hline NPQ & $\begin{array}{l}\text { The non-photochemical quenching that reflects heat } \\
\text { dissipation of excitation energy }\end{array}$ & Calculated as $\left(\mathrm{Fm}-\mathrm{Fm}^{\prime}\right) / \mathrm{Fm}^{\prime}$ \\
\hline ETR & The relative PSII electron transport rate & $\begin{array}{l}\text { Calculated as } \Phi \text { PSII } \times \text { PAR } \times c \times \text { abs, where PAR is the } \\
\text { photosynthetically active radiation } \mathrm{c} \text { is } 0.5 \text {, and abs is the } \\
\text { total light absorption of the leaf taken as } 0.84\end{array}$ \\
\hline$\Phi_{N P Q}$ & $\begin{array}{c}\text { The quantum yield of regulated non-photochemical } \\
\text { energy loss in PSII, that is heat dissipation for } \\
\text { photoprotection }\end{array}$ & Calculated as Fs $/ \mathrm{Fm}^{\prime}-\mathrm{Fs} / \mathrm{Fm}$ \\
\hline$\Phi_{N O}$ & The quantum yield of non-regulated energy loss in PSII & Calculated as Fs/Fm \\
\hline EXC & Excess excitation energy & Calculated as (Fv/Fm - ФPSII)/(Fv/Fm) \\
\hline
\end{tabular}

\subsection{Determination of Oxidative Damage}

Leaf samples were frozen in liquid nitrogen and stored at $-80{ }^{\circ} \mathrm{C}$ for analysis of hydrogen peroxide $\left(\mathrm{H}_{2} \mathrm{O}_{2}\right)$ and malondialdehyde (MDA) content. The level of lipid peroxidation in S. sclarea leaves of control, and 5- and 8-days Cd-treated plants was measured as malondialdehyde (MDA) content determined by the reaction with 2-thiobarbituric acid (TBA), according to the method of Hodges et al. [130]. Hydrogen peroxide $\left(\mathrm{H}_{2} \mathrm{O}_{2}\right)$ was extracted by homogenization with $50 \mathrm{mM} \mathrm{K}$-phosphate buffer $\mathrm{pH}$ (6.5) and determined as described by Hossain et al. [131] after reaction with $0.1 \% \mathrm{TiCl}_{4}$ in $20 \% \mathrm{H}_{2} \mathrm{SO}_{4}$.

The histochemically detection of $\mathrm{H}_{2} \mathrm{O}_{2}$ in leaves was performed as described by Daudi and $\mathrm{O}^{\prime}$ Brien [132] by staining with $1 \% 3,3^{\prime}$-diaminobenzidine (DAB) solution. DAB is oxidized by $\mathrm{H}_{2} \mathrm{O}_{2}$ in the presence of some heme-containing proteins to generate a dark brown precipitate. This precipitate is exploited as a stain to detect the presence and distribution of hydrogen peroxide in plant tissues.

\subsection{Leaf Ultrastructure Observations by Transmission Electron Microscopy}

In order to study leaf ultrastructure alterations after 2 and 5 days of $\mathrm{Cd}$ treatment, leaves from both $\mathrm{Cd}$-treated and untreated plants were excised and segmented with a razor blade into small pieces of $0.5 \times 1 \mathrm{~mm}$. Leaf segments were fixed with $2 \%$ paraformaldehyde plus $4 \%$ glutaraldehyde, in $0.05 \mathrm{M}$ sodium cacodylate buffer, $\mathrm{pH} 7.0$ solution [129]. After a $5 \mathrm{~h}$ fixation at room temperature, the samples were washed with a $0.05 \mathrm{M}$ sodium cacodylate buffer and post-fixed for another $3 \mathrm{~h}$ in a similarly buffered $2 \%$ osmium tetroxide solution (Agar Scientific, Essex, UK). Afterwards, samples were dehydrated in an acetone series, treated with propylene oxide, and embedded in Durcupan ACM resin (Fluka Chemie AG, Buchs, Switzerland). Ultrathin sections (80-90 $\mathrm{nm}$ ) were cut in a ULTROTOME III TYPE 8801A ultramicrotome (LKB, Stockholm, Sweden), equipped with a glass knife, collected on nickel grids. The sections were stained with $2 \%$ uranyl acetate and $1 \%$ lead citrate and examined in a JEOL JEM 1011 (JEOL, Tokyo, Japan) TEM, equipped with a Gatan ES500W (Gatan, Pleasanton, CA, USA) digital camera. Digital electron micrographs were obtained 
with the DigitalMigrograph 3.11.2 (Gatan, Pleasanton, CA, USA) software according to the manufacturer's instructions.

\subsection{Statistical Analyses}

Mean values were calculated from three independent treatments (biological replicates). Statistically significant differences among the means were determined using one-way analysis of variance or two-way ANOVA. Means $( \pm S D)$ were considered statistically different at a level of $p<0.05$.

\section{Conclusions}

Although surplus $\mathrm{Cd}$ accumulation is detrimental to most plants, different strategies of $\mathrm{Cd}$ tolerance and accumulation are adopted by different plant species [97]. When clary sage was exposed to $\mathrm{Cd}$ for a short time, tolerance mechanisms were triggered, with PSII photochemistry to be enhanced, without any defects to chloroplasts, as observed by transmission electron microscopy (Figure 13). However, exposure to a combination of $\mathrm{Cd}$ and high light (Figures 7 and 9), or longer duration exposure to $\mathrm{Cd}$ alone (8 days), resulted in an inhibition of PSII functionality (Figure 10) and [126], pointing out to Cd toxicity. Thus, an activation of PSII function at short time exposures and an inhibition at longer duration suggests a hormetic response (Figure 14), and describes these effects in terms of "adaptive response" and "toxicity", respectively.

Supplementary Materials: The following are available online at https:/ / www.mdpi.com/1422-0 067/22/1/41/s1, Table S1: The definitions of the five main chlorophyll fluorescence parameters (Fo, Fm, Fo' $\mathrm{Fm}^{\prime}$ and $\mathrm{Fs}$ ) measured by the Imaging PAM M-Series system. Figure S1: Transmission Electron Microscopy (TEM) images of control (untreated) chloroplasts and 8 days Cd-treated Salvia sclarea leaves. Figure S2: A typical modulated fluorescence trace showing how $\mathrm{Fo}, \mathrm{F} m, \mathrm{Fo}^{\prime}, \mathrm{F} m^{\prime}$ and Fs, are formed to measure photochemical and non-photochemical parameters.

Author Contributions: Conceptualization, A.D. and M.M.; methodology, I.-D.S.A., I.S. and M.M.; software, I.S., A.H. and M.M.; validation, A.H. and M.M.; formal analysis, I-D.S.A, I.S., A.H. and M.M.; investigation, I-D.S.A., I.S. and A.H.; resources, I.-D.S.A., A.H., A.D., E.A. and M.M.; data curation, I.-D.S.A., I.S., A.H., A.D. and M.M.; writing-original draft preparation, I.-D.S.A., A.H. and M.M.; writing-review and editing, I.-D.S.A., A.H., I.S., A.D., E.A. and M.M.; visualization, A.H. and M.M.; supervision, A.D. and M.M.; project administration, A.D., E.A. and M.M.; funding acquisition, I.-D.S.A., A.H., A.D., E.A. and M.M. All authors have read and agreed to the published version of the manuscript.

Funding: This work was supported by the Agreement for scientific cooperation between the Bulgarian Academy of Sciences and the Aristotle University of Thessaloniki, Greece. A.H. was supported by the Ministry of Science and Higher Education in Poland for statutory activities in Adam Mickiewicz University, Poznań.

Data Availability Statement: The data presented in this study are openly available in [repository name e.g., FigShare] at [doi], reference number [reference number].

Acknowledgments: Seeds of Salvia sclarea used for the experiments were kindly provided by Bio Cultures Ltd. The help of Emmanuel Panteris in using the electron microscope is gratefully acknowledged. Thanks, are also due to the two anonymous reviewers for their corrections and constructive comments that improved the manuscript.

Conflicts of Interest: The authors declare no conflict of interest. The funders had no role in the design of the study; in the collection, analyses, or interpretation of data; in the writing of the manuscript, or in the decision to publish the results.

\section{Appendix A}

\section{Appendix A.1. ICP-MS Operational Conditions}

Operational conditions were optimized daily, using a solution of $\mathrm{Mg}$, In, and $\mathrm{U}$ at a concentration of $1 \mathrm{mg} \mathrm{L}^{-1}$ and $\mathrm{Ba}$ at a concentration of $10 \mathrm{mg} \mathrm{L}^{-1}$ (Smart Tune Solution e Elan DRC II/plus, Atomic Spectroscopy Standard, Perkin Elmer Pure, Perkin 
Elmer, Shelton, CT, USA). Whilst tuning the ICP-MS, compromise conditions for maximum signal intensity of the analyte $\left({ }^{24} \mathrm{Mg}^{+},{ }^{115} \mathrm{In}^{+},{ }^{238} \mathrm{U}^{+}\right)$and minimum ratio of oxide $\left({ }^{140} \mathrm{Ce} 16 \mathrm{O}^{+} /{ }^{140} \mathrm{Ce}<3 \%\right)$ and doubly charged ions $\left({ }^{128} \mathrm{Ba}^{2+} /{ }^{128} \mathrm{Ba}^{+}<3 \%\right)$ were found.

\section{Appendix A.2. Calibration Solutions}

Calibration solutions were prepared by appropriate dilution of $10 \mathrm{mg} \mathrm{L}^{-1}$ multi-elemental stock solution in 5\% $\mathrm{HNO}_{3}$ (Multi-Element Calibration Standard 3, PerkinElmer, MA, USA). The calibration curves were constructed in the concentration ranges: $0.1-100 \mu \mathrm{g} \mathrm{L}^{-1}$ for $\mathrm{Cd}$, $\mathrm{Cu}, \mathrm{Mn}, \mathrm{Zn}$ and $50-1500 \mu \mathrm{g} \mathrm{L}{ }^{-1}$ for $\mathrm{Ca}, \mathrm{Fe}$ and $\mathrm{Mg}$.

\section{Appendix A.3. ICP-MS Instrumental Settings}

The ICP-MS instrumental settings were as follows: (0.89-0.91) $\mathrm{L} \mathrm{min}^{-1}$ sample gas flow, $16 \mathrm{~L} \mathrm{~min}^{-1}$ plasma gas flow, $1.2 \mathrm{~L} \mathrm{~min}^{-1}$ auxiliary gas flow, $1250 \mathrm{~W} \mathrm{RF}$ generator power, dual detector mode, autolens mode. Dynamic reaction cell (DRC) mode with ammonia as reaction gas was used in order to remove the polyatomic interferences. The non-spectral interferences were reduced by diluting the sample and using $10 \mu \mathrm{g} \mathrm{L}^{-1}$ of $\mathrm{Ge}$ and $\mathrm{Rh}$ as internal standard.

\section{Appendix A.4. Data Validation}

For data validation of the applied analytical procedure, two CRMs were used: Trace elements in spinach leaves NIST SRM 1570a (National Institute of Standards and Technology, Gaithersburg, MD, USA) and Water-Trace elements TM-27.4 (National Research Council, Ottawa, ON, Canada).

\section{Appendix A.5. Validation Parameters}

Validation parameters such as linearity, precision, LOD and trueness were evaluated. The calibration curves for the determined elements were linear in the range of calibration standards. Coefficient of correlation $(\mathrm{R})$ values were estimated daily and were greater than 0.999 for all analytes. Residual plots showed a random distribution of residuals around the vertical axis. Precision values were calculated as coefficient of variation $(\mathrm{CV})(\%)$ ranged from $1.7 \%$ to $3.7 \%$ for all elements. Trueness was evaluated by applying the certified reference materials and expressed as recovery (\%). Recovery values ranged from $95 \%$ to $106 \%$ respectively. LOD values were estimated as $3.3 \mathrm{~S} / \mathrm{b}$, where $\mathrm{S}$ means the standard deviation of the result obtained for the blank sample and $b$ is the sensitivity $(n=5)$. The

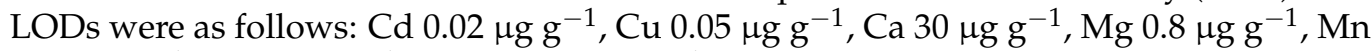
$0.03 \mu \mathrm{g} \mathrm{g}^{-1}$, Fe $40 \mu \mathrm{g} \mathrm{g}^{-1}$ and $\mathrm{Zn} 0.01 \mu \mathrm{g} \mathrm{g}^{-1}$. Measurement traceability was established by applying the certified reference materials.

\section{References}

1. Küpper, H.; Parameswaran, A.; Leitenmaier, B.; Trtílek, M.; Šerlík, I. Cadmium induced inhibition of photosynthesis and long-term acclimation to cadmium stress in the hyperaccumulator Thlaspi caerulescens. New Phytol. 2007, 175, 655-674.

2. Sharma, R.K.; Agrawal, M.; Marshall, F. Heavy metal contamination of soil and vegetables in suburban areas of Varanasi, India. Ecotoxicol. Environ. Saf. 2007, 66, 258-266. [CrossRef] [PubMed]

3. Clemens, S.; Ma, J.F. Toxic heavy metal and metalloid accumulation in crop plants and foods. Ann. Rev. Plant Biol. 2016, 67, 489-512. [CrossRef] [PubMed]

4. Bayçu, G.; Moustaka, J.; Gevrek-Kürüm, N.; Moustakas, M. Chlorophyll fluorescence imaging analysis for elucidating the mechanism of photosystem II acclimation to cadmium exposure in the hyperaccumulating plant Noccaea caerulescens. Materials 2018, 11, 2580. [CrossRef]

5. Dobrikova, A.G.; Apostolova, E.L. Damage and protection of the photosynthetic apparatus under cadmium stress. In Cadmium Toxicity and Tolerance in Plants: From Physiology to Remediation, 1st ed.; Hasanuzzaman, M., Prasad, M.N.V., Fujita, M., Eds.; Academic Press: Cambridge, MA, USA, 2019; pp. 275-298.

6. Moustakas, M.; Hanć, A.; Dobrikova, A.; Sperdouli, I.; Adamakis, I.D.S.; Apostolova, E. Spatial heterogeneity of cadmium effects on Salvia sclarea leaves revealed by chlorophyll fluorescence imaging analysis and laser ablation inductively coupled plasma mass spectrometry. Materials 2019, 12, 2953. [CrossRef] 
7. Bayçu, G.; Gevrek-Kürüm, N.; Moustaka, J.; Csatári, I.; Rognes, S.E.; Moustakas, M. Cadmium-zinc accumulation and photosystem II responses of Noccaea caerulescens to Cd and Zn exposure. Environ. Sci. Pollut. Res. 2017, 24, 2840-2850. [CrossRef]

8. Carvalho, M.E.A.; Castro, P.R.C.; Azevedo, R.A. Hormesis in plants under Cd exposure: From toxic to beneficial element? J. Hazard. Mater. 2020, 384, 121434. [CrossRef]

9. Muszynska, E.; Hanus-Fajerska, E.; Ciarkowska, K. Studies on lead and cadmium toxicity in Dianthus carthusianorum calamine ecotype cultivated in vitro. Plant Biol. 2018, 20, 474-482. [CrossRef]

10. Carvalho, M.E.A.; Piotto, F.A.; Franco, M.R.; Rossi, M.L.; Martinelli, A.P.; Cuypers, A.; Azevedo, R.A. Relationship between Mg, B and Mn status and tomato tolerance against Cd toxicity. J. Environ. Manag. 2019, 240, 84-92. [CrossRef]

11. Kato, F.H.; Carvalho, M.E.A.; Gaziola, S.A.; Piotto, F.A.; Azevedo, R.A. Lysine metabolism and amino acid profile in maize grains from plants subjected to cadmium exposure. Sci. Agric. 2020, 77, e20180095. [CrossRef]

12. Assunção, A.G.L.; Bookum, W.M.; Nelissen, H.J.M.; Vooijs, R.; Schat, H.; Ernst, W.H.O. Differential metal-specific tolerance and accumulation patterns among Thlaspi caerulescens populations originating from different soil types. New Phytol. 2003, 159, 411-419. [CrossRef]

13. Sperdouli, I.; Moustakas, M. Spatio-temporal heterogeneity in Arabidopsis thaliana leaves under drought stress. Plant Biol. 2012, 14, 118-128. [CrossRef] [PubMed]

14. Sperdouli, I.; Moustakas, M. Leaf developmental stage modulates metabolite accumulation and photosynthesis contributing to acclimation of Arabidopsis thaliana to water deficit. J. Plant Res. 2014, 127, 481-489. [CrossRef] [PubMed]

15. Sperdouli, I.; Moustakas, M. A better energy allocation of absorbed light in photosystem II and less photooxidative damage contribute to acclimation of Arabidopsis thaliana young leaves to water deficit. J. Plant Physiol. 2014, 171, 587-593. [CrossRef] [PubMed]

16. Agathokleous, E. Environmental hormesis, a fundamental non-monotonic biological phenomenon with implications in ecotoxicology and environmental safety. Ecotoxicol. Environ. Saf. 2018, 148, 1042-1053. [CrossRef]

17. Christou, A.; Michael, C.; Fatta-Kassinos, D.; Fotopoulos, V. Can the pharmaceutically active compounds released in agroecosystems be considered as emerging plant stressors? Environ. Int. 2018, 114, 360-364. [CrossRef]

18. Muszynska, E.; Labudda, M. Dual role of metallic trace elements in stress biology-from negative to beneficial impact on plants. Int. J. Mol. Sci. 2019, 20, 3117. [CrossRef]

19. Agathokleous, E.; Feng, Z.; Peñuelas, J. Chlorophyll hormesis: Are chlorophylls major components of stress biology in higher plants? Sci. Total Environ. 2020, 726, 138637. [CrossRef]

20. Mittler, R. ROS are good. Trends Plant Sci. 2017, 22, 11-19. [CrossRef]

21. Czarnocka, W.; Karpiński, S. Friend or foe? Reactive oxygen species production, scavenging and signaling in plant response to environmental stresses. Free Radic. Biol. Med. 2018, 122, 4-20. [CrossRef]

22. Agathokleous, E.; Kitao, M.; Harayama, H. On the non-monotonic, hermetic photoprotective response of plants to stress. Dose-Response 2019, 17, 1-3. [CrossRef] [PubMed]

23. Bellini, E.; De Tullio, M.C. Ascorbic acid and ozone: Novel perspectives to explain an elusive relationship. Plants 2019, 8, 122. [CrossRef] [PubMed]

24. Rozhko, T.V.; Nogovitsyna, E.I.; Badun, G.A.; Lukyanchuk, A.N.; Kudryasheva, N.S. Reactive Oxygen Species and low-dose effects of tritium on bacterial cells. J. Environ. Radioact. 2019, 208-209, 106035. [CrossRef] [PubMed]

25. Adamakis, I.D.S.; Sperdouli, I.; Eleftheriou, E.P.; Moustakas, M. Hydrogen peroxide production by the spot-like mode action of bisphenol A. Front. Plant Sci. 2020, 11, 1196. [CrossRef] [PubMed]

26. Malea, P.; Charitonidou, K.; Sperdouli, I.; Mylona, Z.; Moustakas, M. Zinc uptake, photosynthetic efficiency and oxidative stress in the seagrass Cymodocea nodosa exposed to ZnO nanoparticles. Materials 2019, 12, 2101. [CrossRef]

27. Sperdouli, I.; Moustaka, J.; Antonoglou, O.; Adamakis, I.-D.S.; Dendrinou-Samara, C.; Moustakas, M. Leaf age-dependent effects of foliar-sprayed CuZn nanoparticles on photosynthetic efficiency and ROS generation in Arabidopsis thaliana. Materials 2019, 12, 2498. [CrossRef]

28. Roach, T.; Na, C.S.; Stöggl, W.; Krieger-Liszkay, A. The non-photochemical quenching protein LHCSR3 prevents oxygendependent photoinhibition in Chlamydomonas reinhardtii. J. Exp. Bot. 2020, 71, 2650-2660. [CrossRef]

29. Moustakas, M.; Bayçu, G.; Sperdouli, I.; Eroğlu, H.; Eleftheriou, E.P. Arbuscular mycorrhizal symbiosis enhances photosynthesis in the medicinal herb Salvia fruticosa by improving photosystem II photochemistry. Plants 2020, 9, 962. [CrossRef]

30. Nishiyama, Y.; Yamamoto, H.; Allakhverdiev, S.I.; Inaba, M.; Yokota, A.; Murata, N. Oxidative stress inhibits the repair of photodamage to the photosynthetic machinery. EMBO J. 2001, 20, 5587-5594. [CrossRef]

31. Murata, N.; Takahashi, S.; Nishiyama, Y.; Allakhverdiev, S.I. Photoinhibition of photosystem II under environmental stress. Biochim. Biophys. Acta 2007, 1767, 414-421. [CrossRef]

32. Kale, R.; Hebert, A.E.; Frankel, L.K.; Sallans, L.; Bricker, T.M.; Pospíšil, P. Amino acid oxidation of the D1 and D2 proteins by oxygen radicals during photoinhibition of Photosystem II. Proc. Natl. Acad. Sci. USA 2017, 114, 2988-2993. [CrossRef] [PubMed]

33. Szopiński, M.; Sitko, K.; Gieroń, Z.; Rusinowski, S.; Corso, M.; Hermans, C.; Verbruggen, N.; Małkowski, E. Toxic Effects of Cd and $\mathrm{Zn}$ on the photosynthetic apparatus of the Arabidopsis halleri and Arabidopsis arenosa pseudo-metallophytes. Front. Plant Sci. 2019, 10, 748. [CrossRef] [PubMed]

34. Agathokleous, E.; Kitao, M.; Calabrese, E.J. Hormesis: A compelling platform for sophisticated plant science. Trends Plant Sci. 2019, 24, 318-327. [CrossRef] [PubMed] 
35. Shahid, M.; Niazi, N.K.; Rinklebe, J.; Bundschuh, J.; Dumat, C.; Pinelli, E. Trace elements-induced phytohormesis: A critical review and mechanistic interpretation. Crit. Rev. Environ. Sci. Technol. 2020, 50, 1984-2015. [CrossRef]

36. Małkowski, E.; Sitko, K.; Szopiński, M.; Gieroń, Z.; Pogrzeba, M.; Kalaji, H.M.; Zieléznik-Rusinowska, P. Hormesis in plants: The role of oxidative stress, auxins and photosynthesis in corn treated with Cd or Pb. Int. J. Mol. Sci. 2020, 21, 2099. [CrossRef]

37. Kudryasheva, N.S.; Rozhko, T.V. Effect of low-dose ionizing radiation on luminous marine bacteria: Radiation hormesis and toxicity. J. Environ. Radioact. 2015, 142, 68-77. [CrossRef]

38. Agathokleous, E.; Kitao, M.; Calabrese, E.J. Hormesis: Highly generalizable and beyond laboratory. Trends Plant Sci. 2020, 25, 1076-1086. [CrossRef]

39. Calabrese, E.J. Hormetic mechanisms. Crit. Rev. Toxicol. 2013, 43, 580-606. [CrossRef]

40. Agathokleous, E.; Calabrese, E.J. Hormesis: The dose response for the 21st Century: The future has arrived. Toxicology 2019, 425, 152249. [CrossRef]

41. Agathokleous, E.; Feng, Z.; Iavicoli, I.; Calabrese, E.J. The two faces of nanomaterials: A quantification of hormesis in algae and plants. Environ. Int. 2019, 131, 105044. [CrossRef]

42. Calabrese, E.J. Evidence that hormesis represents an "overcompensation" response to a disruption in homeostasis. Ecotoxicol. Environ. Saf. 1999, 42, 135-137. [CrossRef] [PubMed]

43. Kuźma, L.; Kalemba, D.; Rózalski, M.; Rózalska, B.; Wieckowska-Szakiel, M.; Krajewska, U.; Wysokińska, H. Chemical composition and biological activities of essential oil from Salvia sclarea plants regenerated in vitro. Molecules 2009, 14, 1438-1447. [CrossRef] [PubMed]

44. Zheljazkov, V.D.; Nielsen, N.E. Growing clary sage (Salvia sclarea L.) in heavy metal-polluted areas. Acta Hortic. 1996, 426, 309-328. [CrossRef]

45. Khan, N.A.; Singh, S.; Anjum, N.A.; Nazar, R. Cadmium effects on carbonic anhydrase, photosynthesis, dry mass and antioxidative enzymes in wheat (Triticum aestivum) under low and sufficient zinc. J. Plant Interact. 2008, 3, 31-37. [CrossRef]

46. Vassilev, A.; Perez-Sanz, A.; Semane, B.; Carleer, R.; Vangronsveld, J. Cadmium accumulation and tolerance of two Salix genotypes hydroponically grown in presence of cadmium. J. Plant Nutr. 2005, 28, 2159-2177. [CrossRef]

47. Ismail, S.; Khan, F.; Iqbal, M.Z. Phytoremediation: Assessing tolerance of tree species against heavy metal (Pb and Cd) toxicity. Pak. J. Bot. 2013, 45, 2181-2186.

48. Dixit, V.; Pandey, V.; Shyam, R. Differential oxidative responses to cadmium in roots and leaves of pea (Pisum sativum). J. Exp. Bot. 2001, 52, 1101-1109. [CrossRef]

49. Gratão, P.L.; Monteiro, C.C.; Tezotto, T.; Carvalho, R.F.; Alves, L.R.; Peters, L.P.; Azevedo, R.A. Cadmium stress antioxidant responses and root-to-shoot communication in grafted tomato plants. BioMetals 2015, 28, 803-816. [CrossRef]

50. Mizushima, M.Y.B.; Ferreira, B.G.; França, M.G.C.; Almeida, A.A.F.; Cortez, P.A.; Silva, J.V.S.; Jesus, R.M.; Prasad, M.N.V.; Mangabeira, P.A.O. Ultrastructural and metabolic disorders induced by short-term cadmium exposure in Avicennia schaueriana plants and its excretion through leaf salt glands. Plant Biol. 2019, 21, 844-853. [CrossRef]

51. Caldelas, C.; Weiss, D.J. Zinc homeostasis and isotopic fractionation in plants: A review. Plant Soil 2017, 411, 17-46. [CrossRef]

52. Moustakas, M.; Bayçu, G.; Gevrek-Kürüm, N.; Moustaka, J.; Csatári, I.; Rognes, S.E. Spatiotemporal heterogeneity of photosystem II function during acclimation to zinc exposure and mineral nutrition changes in the hyperaccumulator Noccaea caerulescens. Environ. Sci. Pollut. Res. 2019, 26, 6613-6624. [CrossRef] [PubMed]

53. White, P.J.; Brown, P.H. Plant nutrition for sustainable development and global health. Ann. Bot. Lond. 2010, 105, 1073-1080. [CrossRef] [PubMed]

54. Leitenmaier, B.; Küpper, H. Cadmium uptake and sequestration kinetics in individual leaf cell protoplasts of the Cd/Zn hyperaccumulator Thlaspi caerulescens. Plant Cell Environ. 2011, 34, 208-219. [CrossRef] [PubMed]

55. Maestri, E.; Marmiroli, M.; Visioli, G.; Marmiroli, N. Metal tolerance and hyperaccumulation: Costs and trade-offs between traits and environment. Environ. Exp. Bot. 2010, 68, 1-13. [CrossRef]

56. Wójcik, M.; Dresler, S.; Plak, A.; Tukiendorf, A. Naturally evolved enhanced Cd tolerance of Dianthus carthusianorum L. is not related to accumulation of thiol peptides and organic acids. Environ. Sci. Pollut. Res. 2015, 22, 7906-7917. [CrossRef]

57. Sharma, S.S.; Dietz, K.J.; Mimura, T. Vacuolar compartmentalization as indispensable component of heavy metal detoxification in plants. Plant Cell Environ. 2016, 39, 1112-1126. [CrossRef]

58. Verbruggen, N.; Hermans, C.; Schat, H. Mechanisms to cope with arsenic or cadmium excess in plants. Curr. Opin. Plant Biol. 2009, 12, 364-372. [CrossRef]

59. He, H.; Wang, X.; Wu, M.; Guo, L.; Fan, C.; Peng, Q. Cadmium and lead affect the status of mineral nutrients in alfalfa grown on a calcareous soil. Soil Sci. Plant Nutr. 2020, 66, 506-514. [CrossRef]

60. Perfus-Barbeoch, L.; Leonhardt, N.; Vavaddeur, A.; Forestier, C. Heavy metal toxicity: Cadmium permeates through calcium channels and disturbs the plant water status. Plant J. 2002, 32, 539-548. [CrossRef]

61. Gallego, S.M.; Pena, L.B.; Barcia, R.A.; Azpilicueta, C.E.; Iannone, M.F.; Rosales, E.P.; Zawoznik, M.S.; Groppa, M.D.; Benavides, M.P. Unravelling cadmium toxicity and tolerance in plants: Insight into regulatory mechanisms. Environ. Exp. Bot. 2012, 83, 33-46. [CrossRef]

62. Suzuki, N. Alleviation by calcium of cadmium-induced root growth inhibition in Arabidopsis seedlings. Plant Biotechnol. J. 2005, 22, 19-25. [CrossRef] 
63. Li, S.; Yu, J.; Zhu, M.; Zhao, F.; Luan, S. Cadmium impairs ion homeostasis by altering $\mathrm{K}^{+}$and $\mathrm{Ca}^{2+}$ channel activities in rice root hair cells. Plant Cell Environ. 2012, 35, 1998-2013. [CrossRef] [PubMed]

64. Chou, T.S.; Chao, Y.Y.; Huang, W.D.; Hong, C.Y.; Kao, C.H. Effect of magnesium deficiency on antioxidant status and cadmium toxicity in rice seedlings. J. Plant Physiol. 2011, 168, 1021-1030. [CrossRef] [PubMed]

65. Hermans, C.; Chen, J.; Coppens, F.; Inzé, D.; Verbruggen, N. Low magnesium status in plants enhances tolerance to cadmium exposure. New Phytol. 2011, 192, 428-436. [CrossRef] [PubMed]

66. Kudo, H.; Kudo, K.; Uemura, M.; Kawai, S. Magnesium inhibits cadmium translocation from roots to shoots, rather than the uptake from roots, in barley. Botany 2015, 93, 345-351. [CrossRef]

67. Borišev, M.; Pajevic, S.; Nikolic, N.; Orlovic, S.; Župunski, M.; Pilipovic, A.; Kebert, M. Magnesium and iron deficiencies alter Cd accumulation in Salix viminalis L. Int. J. Phytoremediat. 2016, 18, 164-170. [CrossRef]

68. Carvalho, M.E.A.; Castro, P.R.C.; Kozak, M.; Azevedo, R.A. The sweet side of misbalanced nutrients in cadmium-stressed plants. Ann. Appl. Biol. 2020, 176, 275-284. [CrossRef]

69. Das, P.; Samantaray, S.; Rout, G.R. Studies on cadmium toxicity in plants: A review. Environ. Pollut. 1997, 98, 29-36. [CrossRef]

70. Clemens, S. Toxic metal accumulation, responses to exposure and mechanisms of tolerance in plants. Biochimie 2006, 88, 1707-1719. [CrossRef]

71. Yoshihara, T.; Hodoshima, H.; Miyano, Y.; Shoji, K.; Shimada, H.; Goto, F. Cadmium inducible Fe deficiency responses observed from macro and molecular views in tobacco plants. Plant Cell Rep. 2006, 25, 365-373. [CrossRef]

72. Xu, S.S.; Lin, S.Z.; Lai, Z.X. Cadmium impairs iron homeostasis in Arabidopsis thaliana by increasing the polysaccharide contents and the iron-binding capacity of root cell walls. Plant Soil 2015, 392, 71-85. [CrossRef]

73. Sasaki, A.; Yamaji, N.; Yokosho, K.; Ma, J.F. Nramp5 is a major transporter responsible for manganese and cadmium uptake in rice. Plant Cell 2012, 24, 2155-2167. [CrossRef] [PubMed]

74. Zhao, F.J.; Wang, P. Arsenic and cadmium accumulation in rice and mitigation strategies. Plant Soil 2020, 446, 1-21. [CrossRef]

75. Guo, Q.; Meng, L.; Zhang, Y.N.; Mao, P.C.; Tian, X.X.; Li, S.S.; Zhang, L. Antioxidative systems, metal ion homeostasis and cadmium distribution in Iris lactea exposed to cadmium stress. Ecotoxicol. Environ. Saf. 2017, 139, 50-55. [CrossRef] [PubMed]

76. Yang, X.E.; Feng, Y.; He, Z.L.; Stoffella, P.J. Molecular mechanisms of heavy metal hyperaccumulation and phytoremediation. J. Trace Elem. Med. Biol. 2005, 18, 339-353. [CrossRef] [PubMed]

77. Zhang, X.F.; Xia, H.P.; Li, Z.A.; Zhuang, P.; Cao, B. Potential of four forage grasses in remediation of Cd and Zn contaminated soils. Bioresour. Technol. 2010, 101, 2063-2066. [CrossRef]

78. Yoon, J.; Cao, X.; Zhou, Q.; Ma, L.Q. Accumulation of $\mathrm{Pb}, \mathrm{Cu}$, and $\mathrm{Zn}$ in native plants growing on a contaminated Florida site. Sci. Total Environ. 2006, 368, 456-464. [CrossRef]

79. Lokhande, V.H.; Srivastava, S.; Patade, V.Y.; Dwivedi, S.; Tripathi, R.D.; Nikam, T.D.; Suprasanna, P. Investigation of arsenic accumulation and tolerance potential of Sesuvium portulacastrum (L.) L. Chemosphere 2011, 82, 529-534. [CrossRef]

80. Feng, J.; Lin, Y.; Yang, Y.; Shen, Q.; Huang, J.; Wang, S.; Zhu, X.; Li, Z. Tolerance and bioaccumulation of Cd and Cu in Sesuvium portulacastrum. Ecotoxicol. Environ. Saf. 2018, 147, 306-312. [CrossRef]

81. Müller, P.; Li, X.P.; Niyogi, K.K. Non-photochemical quenching. A response to excess light energy. Plant Physiol. 2001, 125, 1558-1566. [CrossRef]

82. Gawroński, P.; Witoń, D.; Vashutina, K.; Bederska, M.; Betliński, B.; Rusaczonek, A.; Karpiński, S. Mitogen-activated protein kinase 4 is a salicylic acid-independent regulator of growth but not of photosynthesis in Arabidopsis. Mol. Plant 2014, 7, 1151-1166. [CrossRef] [PubMed]

83. Moustaka, J.; Tanou, G.; Giannakoula, A.; Panteris, E.; Eleftheriou, E.P.; Moustakas, M. Anthocyanin accumulation in poinsettia leaves and its functional role in photo-oxidative stress. Environ. Exp. Bot. 2020, 175, 104065. [CrossRef]

84. Li, X.; Wakao, S.; Fischer, B.B.; Niyogi, K.K. Sensing and responding to excess light. Annu. Rev. Plant Biol. 2009, 60, 239-260. [CrossRef] [PubMed]

85. Fu, X.; Liu, C.; Li, Y.; Liao, S.; Cheng, H.; Tu, Y.; Zhu, X.; Chen, K.; He, Y.; Wang, G. The coordination of OsbZIP72 and OsMYBS2 with reverse roles regulates the transcription of OsPsbS1 in rice. New Phytol. 2020. [CrossRef]

86. Külheim, C.; Ågren, J.; Jansson, S. Rapid regulation of light harvesting and plant fitness in the field. Science 2002, 297, 91-93. [CrossRef] [PubMed]

87. Li, X.; Müller-Moulé, P.; Gilmore, A.M.; Niyogi, K.K. PsbS-dependent enhancement of feedback de-excitation protects photosystem II from photoinhibition. Proc. Natl. Acad. Sci. USA 2002, 99, 15222-15227. [CrossRef]

88. Moustaka, J.; Moustakas, M. Photoprotective mechanism of the non-target organism Arabidopsis thaliana to paraquat exposure. Pest. Biochem. Physiol. 2014, 111, 1-6. [CrossRef]

89. Moustaka, J.; Tanou, G.; Adamakis, I.D.; Eleftheriou, E.P.; Moustakas, M. Leaf age dependent photoprotective and antioxidative mechanisms to paraquat-induced oxidative stress in Arabidopsis thaliana. Int. J. Mol. Sci. 2015, 16, 13989-14006. [CrossRef]

90. Ruban, A.V. Nonphotochemical chlorophyll fluorescence quenching: Mechanism and effectiveness in protecting plants from photodamage. Plant Physiol. 2016, 170, 1903-1916. [CrossRef]

91. Kalaji, M.H.; Carpentier, R.; Allakhverdiev, S.I.; Bosa, K. Fluorescence parameters as an early indicator of light stress in barley. J. Photochem. Photobiol. B 2012, 112, 1-6. [CrossRef] 
92. Moustaka, J.; Ouzounidou, G.; Bayçu, G.; Moustakas, M. Aluminum resistance in wheat involves maintenance of leaf Ca ${ }^{2+}$ and $\mathrm{Mg}^{2+}$ content, decreased lipid peroxidation and $\mathrm{Al}$ accumulation, and low photosystem II excitation pressure. BioMetals 2016, 29, 611-623. [CrossRef] [PubMed]

93. Moustaka, J.; Ouzounidou, G.; Sperdouli, I.; Moustakas, M. Photosystem II is more sensitive than photosystem I to $\mathrm{Al}^{3+}$ induced phytotoxicity. Materials 2018, 11, 1772. [CrossRef] [PubMed]

94. Takahashi, S.; Badger, M.R. Photoprotection in plants: A new light on photosystem II damage. Trends Plant Sci. 2011, 16, 53-60. [CrossRef] [PubMed]

95. Dietz, K.J.; Pfannschmidt, T. Novel regulators in photosynthetic redox control of plant metabolism and gene expression. Plant Physiol. 2011, 155, 1477-1485. [CrossRef] [PubMed]

96. Kendig, E.L.; Le, H.H.; Belcher, S.M. Defining hormesis: Evaluation of a complex concentration response phenomenon. Int. J. Toxicol. 2010, 29, 235-246. [CrossRef]

97. Szopiński, M.; Sitko, K.; Rusinowski, S.; Zieleźnik-Rusinowska, P.; Corso, M.; Rostański, A.; Rojek-Jelonek, M.; Verbruggen, N.; Małkowski, E. Different strategies of Cd tolerance and accumulation in Arabidopsis halleri and Arabidopsis arenosa. Plant Cell Environ. 2020, 43, 3002-3019. [CrossRef]

98. Tang, L.; Yao, A.; Yuan, M.; Tang, Y.; Liu, J.; Liu, X.; Qiu, R. Transcriptional up-regulation of genes involved in photosynthesis of the $\mathrm{Zn} / \mathrm{Cd}$ hyperaccumulator Sedum alfredii in response to zinc and cadmium. Chemosphere 2016, 164, 190-200. [CrossRef]

99. Lombi, E.; Zhao, F.J.; Dunham, S.J.; McGrath, S.P. Cadmium accumulation in populations of Thlaspi caerulescens and Thlaspi goesingense. New Phytol. 2000, 145, 11-20. [CrossRef]

100. Faller, P.; Kienzler, K.; Krieger-Liszkay, A. Mechanism of $\mathrm{Cd}^{2+}$ toxicity: $\mathrm{Cd}^{2+}$ inhibits photoactivation of photosystem II by competitive binding to the essential $\mathrm{Ca}^{2+}$ site. Biochim. Biophys. Acta 2005, 1706, 158-164. [CrossRef]

101. Ekmekçi, Y.; Tanyolaç, D.; Ayhan, B. Effects of cadmium on antioxidant enzyme and photosynthetic activities in leaves of two maize cultivars. J. Plant Physiol. 2008, 65, 600-611. [CrossRef]

102. Parmar, P.; Kumari, N.; Sharma, V. Structural and functional alterations in photosynthetic apparatus of plants under cadmium stress. Bot. Stud. 2013, 54, 45. [CrossRef] [PubMed]

103. Dobrikova, A.G.; Yotsova, E.K.; Börner, A.; Landjeva, S.P.; Apostolova, E.L. The wheat mutant DELLA-encoding gene (Rht-B1c) afects plant photosynthetic responses to cadmium stress. Plant Physiol. Biochem. 2017, 114, 10-18. [CrossRef]

104. Yotsova, E.K.; Dobrikova, A.G.; Stefanov, M.; Misheva, S.; Bardácová, M.; Matusíková, I.; Zideková, L.; Blehová, A.; Apostolova, E. Effects of cadmium on two wheat cultivars depending on different nitrogen supply. Plant Physiol. Biochem. 2020, 155, 789-799. [CrossRef]

105. Hanć, A.; Małecka, A.; Kutrowska, A.; Bagniewska-Zadworna, A.; Tomaszewska, B.; Barałkiewicz, D. Direct analysis of elemental biodistribution in pea seedlings by LA-ICP-MS, EDX and confocal microscopy: Imaging and quantification. Microchem. J. 2016, 128, 305-311. [CrossRef]

106. Małecka, A.; Konkolewska, A.; Hanć, A.; Barałkiewicz, B.; Ciszewska, L.; Ratajczak, E.; Staszak, A.M.; Kmita, H.; Jarmuszkiewicz, W. Insight into the phytoremediation capability of Brassica juncea (v. Malopolska): Metal accumulation and antioxidant enzyme activity. Int. J. Mol. Sci. 2019, 20, 4355-4372.

107. Adamakis, I.D.S.; Malea, P.; Sperdouli, I.; Panteris, E.; Kokkinidi, D.; Moustakas, M. Evaluation of the spatiotemporal effects of bisphenol A on the leaves of the seagrass Cymodocea nodosa. J. Hazard. Mater. 2021, 404, 124001. [CrossRef]

108. Arena, C.; Figlioli, F.; Sorrentino, M.C.; Izzo, L.G.; Capozzi, F.; Giordano, S.; Spagnuolo, V. Ultrastructural, protein and photosynthetic alterations induced by $\mathrm{Pb}$ and $\mathrm{Cd}$ in Cynara cardunculus L. and its potential for phytoremediation. Ecotoxicol. Environ. Saf. 2017, 145, 83-89. [CrossRef]

109. Sorrentino, M.C.; Capozzi, F.; Amitrano, C.; Giordano, S.; Arena, C.; Spagnuolo, V. Performance of three cardoon cultivars in an industrial heavy metal contaminated soil: Effects on morphology, cytology and photosynthesis. J. Hazard. Mater. 2018, 351, 131-137. [CrossRef]

110. Delhaize, E.; Schachtman, D.; Kochian, L.; Ryan, P.R. Mineral Nutrient Acquisition, Transport, and Utilization. In Biochemistry and Molecular Biology of Plants, 2nd ed.; Buchanan, B.B., Gruissem, W., Russell, L.J., Eds.; John Wiley \& Sons, Ltd.: Hoboken, NJ, USA, 2015; pp. 1101-1131.

111. Souza, V.L.; de Almeida, A.A.; Lima, S.G.; de M Cascardo, J.C.; da C Silva, D.; Mangabeira, P.A.; Gomes, F.P. Morphophysiological responses and programmed cell death induced by cadmium in Genipa americana L. (Rubiaceae). BioMetals 2011, $24,59-71$. [CrossRef]

112. Barcelo, J.; Vazquez, M.D.; Poschenrieder, C.H. Structural and ultrastructural disorders in cadmium-treated bush bean plants (Phaseolus vulgaris L.). New Phytol. 1988, 108, 37-49. [CrossRef]

113. Ouzounidou, G.; Moustakas, M.; Eleftheriou, E.P. Physiological and ultrastructural effects of cadmium on wheat (Triticum aestivum L.) leaves. Arch. Environ. Contam. Toxicol. 1997, 32, 154-160. [CrossRef] [PubMed]

114. Daud, M.K.; Variath, M.T.; Ali, S.; Najeeb, U.; Jamil, M.; Hayat, Y.; Dawoo, M.; Khan, M.I.; Zaffar, M.; Cheema, S.A.; et al. Cadmium-induced ultramorphological and physiological changes in leaves of two transgenic cotton cultivars and their wild relative. J. Hazard. Mater. 2009, 168, 614-625. [CrossRef] [PubMed]

115. Najeeb, U.; Jilani, G.; Ali, S.; Sarwar, M.; Xu, L.; Zhou, W. Insights into cadmium induced physiological and ultra-structural disorders in Juncus effusus L. and its remediation through exogenous citric acid. J. Hazard. Mater. 2011, 186, 565-574. [CrossRef] [PubMed] 
116. Pietrini, F.; Iannelli, M.A.; Pasqualini, S.; Massacci, A. Interaction of cadmium with glutathione and photosynthesis in developing leaves and chloroplasts of Phragmites australis (Cav.) Trin. ex Steudel. Plant Physiol. 2003, 133, 829-837. [CrossRef] [PubMed]

117. Gratão, P.L.; Monteiro, C.C.; Rossi, M.L.; Martinelli, A.P.; Peres, L.E.P.; Medici, L.O.; Lea, P.J.; Azevedo, R.A. Differential ultrastructural changes in tomato hormonal mutants exposed to cadmium. Environ. Exp. Bot. 2009, 67, 387-394. [CrossRef]

118. Vazquez, M.D.; Poschenrieder, C.; Barcelo, J. Pulvinus structure and leaf abscission in cadmium-treated bean plants (Phaseolus vulgaris). Can. J. Bot. 1989, 67, 2756-2764. [CrossRef]

119. Savvides, A.; Ali, S.; Tester, M.; Fotopoulos, V. Chemical priming of plants against multiple abiotic stresses: Mission possible? Trends Plant Sci. 2016, 21, 329-340. [CrossRef]

120. Tanou, G.; Fotopoulos, V.; Molassiotis, A. Priming against environmental challenges and proteomics in plants: Update and agricultural perspectives. Front. Plant Sci. 2012, 3, 216. [CrossRef]

121. Calabrese, E.J. Preconditioning is hormesis part II: How the conditioning dose mediates protection: Dose optimization within temporal and mechanistic frameworks. Pharmacol. Res. 2016, 110, 265-275. [CrossRef]

122. Lambrev, P.H.; Miloslavina, Y.; Jahns, P.; Holzwarth, A.R. On the relationship between non-photochemical quenching and photoprotection of photosystem II. Biochim. Biophys. Acta 2012, 1817, 760-769. [CrossRef]

123. Moustakas, M.; Malea, P.; Zafeirakoglou, A.; Sperdouli, I. Photochemical changes and oxidative damage in the aquatic macrophyte Cymodocea nodosa exposed to paraquat-induced oxidative stress. Pest. Biochem. Physiol. 2016, 126, 28-34. [CrossRef] [PubMed]

124. Moustakas, M.; Malea, P.; Haritonidou, K.; Sperdouli, I. Copper bioaccumulation, photosystem II functioning and oxidative stress in the seagrass Cymodocea nodosa exposed to copper oxide nanoparticles. Environ. Sci. Pollut. Res. 2017, 24, 16007-16018. [CrossRef]

125. Antonoglou, O.; Moustaka, J.; Adamakis, I.D.; Sperdouli, I.; Pantazaki, A.; Moustakas, M.; Dendrinou-Samara, C. Nanobrass CuZn nanoparticles as foliar spray non phytotoxic fungicides. ACS Appl. Mater. Interfaces 2018, 10, 4450-4461. [CrossRef]

126. Dobrikova, A.; Apostolova, E.; Hanć, A.; Yotsova, E.; Borisova, P.; Sperdouli, I.; Adamakis, I.D.S.; Moustakas, M. Cadmium toxicity on Salvia sclarea: An integrative response of elemental uptake, oxidative stress markers, leaf structure and photosynthesis. Ecotoxicol. Environ. Saf. 2021. [CrossRef]

127. Borowiak, K.; Budka, A.; Lisiak-Zielińska, M.; Hanć, A.; Zbierska, J.; Barałkiewicz, D.; Kayzer, D.; Gaj, R.; Szymczak-Graczyk, A.; Kanclerz, J. Accumulation of airborne toxic elements and photosynthetic performance of Lolium multiflorum L. leaves. Processes 2020, 8, 1013. [CrossRef]

128. Lichtenthaler, H.K. Chlorophylls and carotenoids pigments of photosynthetic membranes. Methods Enzymol. 1987, 148, 350-382.

129. Moustaka, J.; Panteris, E.; Adamakis, I.D.S.; Tanou, G.; Giannakoula, A.; Eleftheriou, E.P.; Moustakas, M. High anthocyanin accumulation in poinsettia leaves is accompanied by thylakoid membrane unstacking, acting as a photoprotective mechanism, to prevent ROS formation. Environ. Exp. Bot. 2018, 154, 44-55. [CrossRef]

130. Hodges, D.M.; DeLong, J.M.; Forney, C.F.; Prange, R.K. Improving the thiobarbituric acid-reactive-substances assay for estimating lipid peroxidation in plant tissues containing anthocyanin and other interfering compounds. Planta 1999, 207, 604-611. [CrossRef]

131. Hossain, M.A.; Hasanuzzaman, M.; Fujita, M. Up-regulation of antioxidant and glyoxalase systems by exogenous glycinebetaine and proline in mung bean confer tolerance to cadmium stress. Physiol. Mol. Biol. Plants 2010, 26, 259-272. [CrossRef]

132. Daudi, A.; O'Brien, J.A. Detection of hydrogen peroxide by DAB staining in Arabidopsis leaves. BioProtocol. 2012,2 , e263. [CrossRef] 